\title{
OS DESAFIOS DAS POSTURAS ENUNCIATIVAS E DE SUA UTILIZAÇÃO EM DIDÁTICA ${ }^{i}$
}

\begin{abstract}
Alain Rabateli
Resumo: Este artigo faz um balanço sobre a questão das posturas enunciativas. (1) Distingue a coenunciação da colocução e define as posturas a partir do papel dos enunciadores na coconstrução dos pontos de vista: coenunciação; super-enunciação; sub-enunciação. Essas três posturas permitem dar conta mais detalhadamente dos continuum entre consenso e dissenso, articulando a construção do dizer, ao longo do discurso, com as dimensões cognitivas e interacionais. (2) presenta o quadro teórico enunciativo das posturas, cruzando uma concepção ampliada da enunciação (incipiente em Benveniste), a disjunção locutor/enunciador de Ducrot e as teorias da interação. (3) Apresenta uma genealogia das posturas, por meio da análise de situações interacionais e polissemióticas complexas. (4) Propõe uma análise inédita de um corpus de iniciação a uma língua estrangeira na escola primária. Por fim, o artigo conclui sobre a pertinência de considerar as posturas no estudo dos conceitos de contrato didático e de partilha, ligados à cronogênese e à topogênese.
\end{abstract}

Palavras-chave: Coenunciação. Sub-enunciação. Super-enunciação. Interações didáticas.

Abstract: This paper aims to give an account on enunciative stances. (1) It distinguishes co-énonciation from co-locution and define stances based on the role of speakers in the co-construction of points of view: co-énonciation; super-énonciation; sub-énonciation. These three stances enable us to deal more efficiently with the continuum between consensus and dissensus, articulating the construction of discourse with the cognitive and interactional dimensions. (2) It presents an enunciative theoretical framework about stances, that considers an expanded conception of énonciation (still incipient in Benveniste), the disjunction between locutor and enunciator in Ducrot and interactional theories. (3) It presents a genealogy of stances, through an original analysis of a corpus of second language learning at school. Lastly, the paper defends the pertinence of considering stances in the study of the didactic and the sharing contracts, associated with chronogenesis and topogenesis.

Keywords: Co-énonciation. Sub-énonciation. Super-énonciation. Didactic Interactions.

i A Revista EID\&A agradece vivamente aos editores da revista Éducation et didactique pela autorização da publicação desta tradução, a partir do original: RABATEL, Alain. Les enjeux des postures énonciatives et de leur utilisation en didactique. Éducation et didactique, v. 1, n. 2, sep.2007.

ii Professor de Ciências da Linguagem da Universidade de Lyon 1 e membro da escola de doutorado da Universidade de Lyon 2, França. E-mail: alain.rabatel@univ-lyon1.fr. 
EID\&A - Revista Eletrônica de Estudos Integrados em Discurso e Argumentação, Ilhéus, n. 12, jul/dez.2016.

\section{Introdução}

Depois de mais ou menos quinze publicações dedicadas às posturas enunciativas, chega o tempo de fazer um balanço. Sem esperar o livro que permitirá isso, aproveitamos a ocasião para apresentar ao leitor as razões que nos levaram a redefinir os contornos das concepções tradicionais da coenunciação e propor ao mesmo tempo os conceitos de super-enunciação e sub-enunciação. Esse procedimento genealógico dará um lugar importante ao que se apaga frequentemente nas análises, isto é, o pano de fundo de representações e conceitos que influem na escolha dos métodos, das ferramentas ou dos objetivos de pesquisa.

Mas, antes de entrar nessa gênese, é bom exemplificar rapidamente o que entendemos por posturas de coenunciação, de super-enunciação e de sub-enunciação. Analisemos rapidamente um exemplo de produção colaborativa dos discursos que tomamos emprestado de Jeanneret:

(1) A Isso não nos interessa

B Como é preciso descrevê-la

A Sim como é preciso descrevê-la

(JEANNERET, 1999, p. 98)

Em (1), A ratifica a proposta de B procedendo a uma retomada de formulação. Existe aí um acordo dos dois locutores e enunciadores na construção de um ponto de vista. Mas é sempre possível imaginar situações nas quais o locutor $B$ propõe um fim de enunciado iniciado por $A$, que corresponda ao que $A$ queria dizer (porque $B$ compreendeu aquilo de que ele replicava ou que a reformulação era previsível), sem que, por outro lado, B adira ao ponto de vista que ele formula, enquanto locutor, mas que ele não retome por sua própria conta, enquanto enunciador. É o que se passaria se, no lugar de (1), houvesse o seguinte encadeamento:

(2) A Isso não nos interessa

B Como é preciso descrevê-la

A Sim como é preciso descrevê-la

B Dito isso, a questão do como não tem grande interesse

Em (2), B interrompe A, indo no sentido de A, sem por outro lado aderir a seu ponto de vista (doravante PVD). Logo, é necessário distinguir a colocução ou (coformulação) da coenunciação efetiva, assumida por A e B. Voltaremos às noções de PDV, de enunciador, de locutor, mas, por ora, digamos que as 
EID\&A - Revista Eletrônica de Estudos Integrados em Discurso e Argumentação, llhéus, n. 12, jul/dez.2016.

posturas se definem pela posição que adota um enunciador na expressão de um ponto de vista. O locutor, instância de produção física do enunciado, é dissociado da instância modal $^{1}$ - ou enunciador - que toma o PDV considerando-o como verdadeiro, ou, ao menos, como correspondente à sua maneira de $v^{2}$; as duas instâncias se sobrepõem com frequência, mas devem, todavia, ser distinguidas teoricamente, pois elas dão conta do dialogismo estrutural que permite aos locutores exprimir PDVs sobre os quais eles não estão sempre de acordo.

Eis porque reservaremos aqui a noção de coenunciação a uma troca na qual a colocução revela um acordo dos dois locutores com o que eles enunciam, fazendo desse enunciado, coconstruído e apreendido pelos dois enunciadores ${ }^{3}$, a expressão de um ponto de vista comum. E acrescentaremos à coenunciação ${ }^{4}$, assim redefinida, duas posturas complementares, a super- e a sub-enunciação, a fim de compreender melhor o investimento dos enunciadores na construção interacional dos pontos de vista e na sua apreensão enunciativa.

Certamente, é difícil distinguir o que decorre da "coprodução de um discurso monológico" com acordo dos dois colocutores (o que chamamos de coenunciação) daquela que se produz sem seu acordo. Mas os interactantes levando em conta o conjunto dos parâmetros linguísticos, prosódicos, entonativos, paraverbais que concorrem para a apreensão dos enunciados (CULIOLI, 2002, p. 97) - não se enganam, geralmente, na interpretação dos discursos de seus interlocutores. No mais, se há erro de interpretação, ele é

\footnotetext{
${ }^{1} \mathrm{O}$ termo de instância é utilizado por Ducrot para distinguir as fontes que interagem na realização dos enunciados: trata-se, além do sujeito falante, que tem uma existência extralinguística, do locutor e do enunciador. Nós falamos indiferentemente de enunciador ou de sujeito modal (a expressão de Bally), segundo uma concepção larga de modalidade que não se reduz às modalidades lógicas e que sublinha que todas as escolhas de referenciação são tributárias de um ponto de vista do enunciador, preponderante na recepção das mensagens, como é também o caso com as modalidades epistêmicas, deônticas: ver Rabatel (2005b). Sobre essa questão de apreensão, ver Rabatel (2008), no prelo, assim como os trabalhos do colóquio de apreensão enunciativa, Anvers, 10 e 13 de janeiro, <www.commitment2007@ua.ac.be > e infra, nota 12.

${ }^{2} \mathrm{O}$ que volta a dizer que o enunciador aprecia sempre os enunciados em função de uma relação com o verdadeiro que não tem a sempre a mesma significação: as verdades pessoais (EUVERDADEIRO) não têm as mesmas implicações que as verdades universais (NÓS-VERDADEIRO).

${ }^{3}$ Isto é, assumido como verdadeiro, pelos dois enunciadores, por sua própria conta. Dito de outra forma, um enunciado apreendido não é apenas um enunciado julgado verdadeiro de um ponto de vista geral (NÓS-VERDADEIRO), ele é julgado verdadeiro para os dois enunciadores que o tomam por sua própria conta (EU-VERDADEIRO). É preciso distinguir o fato de levar em conta uma verdade e o de retomá-la por sua própria conta, que, apenas, decorre da apreensão no sentido estrito.

${ }^{4}$ Culioli escreve co-enunciação com um hífen. Haja vista a diferença de definição assim como a tendência atual à supressão de hífens, nas palavras compostas, escrevemos coenunciação, subenunciação e superenunciação em uma só palavra (N.T.: Na tradução deste texto para o português brasileiro, consideramos as orientações do acordo ortográfico em vigor).
} 
EID\&A - Revista Eletrônica de Estudos Integrados em Discurso e Argumentação, Ilhéus, n. 12, jul/dez.2016.

sempre levantado no desenrolar da interação: é uma das razões pelas quais nós tratamos das posturas sem limitá-las no plano de uma intervenção, ou de uma troca, mas integrando-as em sequências ${ }^{5}$, mesmo se os fenômenos surgirem em um contexto mais restrito, no plano sintático ${ }^{6}$.

Essas primeiras precisões sendo trazidas, exemplifiquemos primeira e rapidamente essas posturas, depois de tê-las definido como segue, a partir da ideia fundamental de que, de um ponto de vista ideacional, a coconstrução de PDV não é a realização de um querer-dizer preexistente à interação. A coenunciação corresponde à coconstrução pelos locutores de um PDV comum, que os engaja enquanto enunciadores. A super-enuciação é definida como a coconstrução desigual de um PDV dominante encenando o papel de tópico discursivo ${ }^{7}$.

A sub-enunciação consiste na coconstrução desigual de um PDV dominado: o PDV sub-enunciado reside no fato de que o contexto de predicação $^{8}$ é apresentado como pertencente a um locutor/enunciador anterior, enquanto que a própria predicação, que emana do locutor subenunciador, é apresentada como decorrente do que precede, de maneira que o locutor não é plenamente o enunciador do PDV, ele o apresenta como sendo referido a uma outra instância (um indivíduo, uma norma, uma instituição, a verdade), fazendo entender que esse PDV é principalmente o de um outro antes de ser o seu.

\footnotetext{
${ }^{5}$ A sequência é a unidade intermediária entre a interação (incursão segundo a Escola de Genebra) e a troca, que é a menor unidade dialogal, composta de um número variável de intervenções. Quanto à intervenção (cf. supra, Jeanneret), é a maior unidade monologal/monológica; ela se constitui de vários atos de fala. Dois critérios foram avançados para identificar uma sequência, o critério temático por um lado, o transacional (ou pragmático) por outro, é certo que esses critérios são muito maleáveis, e que os contornos de uma sequência são sempre sujeitos a discussão (TRAVERSO, 1996, p. 30).

${ }^{6}$ No plano sintático, coconstrução de um PDV co-, super- ou sub-enunciado, pode versar tanto sobre um segmento mínimo (concordância em um grupo nominal, premissas, contexto de predicação) quanto sobre um conjunto discursivo mais importante (contexto de predicação e a própria predicação).

${ }^{7}$ Ou seja, tema nocional (retomado tal qual ou reformulado pelos interlocutores), que estrutura várias trocas, até mesmo organiza um sequência.

${ }^{8}$ Um julgamento, ou predicação, consiste em seu tema (o suporte de um julgamento) e no que é dito sobre este (o discurso ou aporte da informação): o contexto de predicação corresponde ao tema. Mas, diferentemente da terminologia antiga, falar de contexto de predicação remete a dizer que a maneira de nomear o tema orienta a interpretação do conteúdo proposto. A diferença não aparece muito quando se trabalha em enunciados descontextualizados sem desafio, mas em contexto, isso ocorre de outra forma. NB: o tema, ou suporte de informação, que se situa no plano de uma proposição, não é equivalente ao tema (= tópico discursivo) como noção que desenvolve em uma sequência. Mas, não é por acaso que, se for o mesmo termo, as noções sendo porosas...
} 
EID\&A - Revista Eletrônica de Estudos Integrados em Discurso e Argumentação, Ilhéus, n. 12, jul/dez.2016.

Haja vista a complexidade dos problemas e uma vez que, na quarta parte, nós analisaremos as interações didáticas orais, começaremos citando exemplos de coenunciação, de sub-enunciação e de super-enunciação na escrita: primeiro porque os fenômenos aparecem aí menos perturbados que na oralidade, sobretudo em contextos didáticos onde a necessidade de construir saberes complica a expressão de um dizer tateante por natureza. Em seguida, porque isso permite insistir no fato de que as posturas são um fenômeno geral $^{9}$, quaisquer que sejam suas diferenças, segundo os gêneros da escrita ou da oralidade.

\section{Exemplos de coenunciação}

Lejeune (2006), sem utilizar a expressão "coenunciação", analisa este exemplo evocando uma fusão das instâncias de validação:

(3) Outro fator positivo: o Instituto Nacional de Estatística em Estudos Econômicos prevê uma pequena diminuição do ritmo de crescimento do desemprego, cuja taxa em relação à população ativa poderia não ultrapassar $12 \%$ [para o segundo semestre de 1993] enquanto que o número de $12,5 \%$ tinha avançado em julho. É verdade que essa relativa melhora poderia ser explicada essencialmente pelo desenvolvimento dos estágios e dos dispositivos de conversão que compensaria o impacto das supressões de emprego (5/11/1993 in LEJEUNE, 2006, grifos do autor).

Essa coenunciação entre o jornalista A. Vernholes e o enunciador da "Nota de conjuntura" do INSEE é marcada pelo fato de que o texto fonte é retomado e validado por Vernholes ("leve diminuição do ritmo de crescimento do desemprego", "relativa melhora”). A coenunciação é lida também a partir dos encadeamentos lógico-argumentativos, uma vez que a melhora dos números, marcada nos itálicos pelo jornalista ("é verdade que") justifica o diagnóstico do INSEE baseando-se em... números do INSEE, os sinais de distanciamento (condicional) e a natureza das causas que exprimem o acordo dos enunciadores em relação à "leve diminuição".

A imbricação dos argumentos na expressão do ponto de vista é da mesma ordem em (4):

(4) CARÁTER: [...] É necessário tratar isso, como se diz, segundo uma fórmula célebre de Heráclito, "o caráter de um homem é seu demônio" ou seu destino:

\footnotetext{
${ }^{9}$ Por isso nossos exemplos são voluntariamente muito heterogêneos, tomando emprestado da imprensa escrita ou audiovisual, do discurso filosófico ou das trocas didáticas.
} 
EID\&A - Revista Eletrônica de Estudos Integrados em Discurso e Argumentação, Ilhéus, n. 12, jul/dez.2016.

porque o caráter é aquele que faz escolhas no homem, algo que este não faz (Compte-Sponville, Dicionário filosófico 2001, p. 98).

A fusão lógico-argumentativa na definição do caráter é marcada pelo fato de que a citação de Heráclito justifica os comentários anteriores de Comte-Sponville, antes que a justificação não seja em si mesmo justificada pelo comentário final desse último, de maneira que as duas vozes dos locutores construam um mesmo ponto de vista partilhado.

\section{Exemplos de superenunciação}

(5) AUTENTICIDADE: A verdade sobre si e de si para si. É o contrário da má-fé. Qual seria, então, um sinônimo da boa-fé? Principalmente seu nome moderno e pouco pretensioso. As duas noções não se recobrem totalmente. Ser de boa-fé é amar a verdade mais que si. Ser autêntico, para muitos dos nossos contemporâneos, é, sobretudo, amar a verdade tal como é (Compte-Sponville, Dicionário filosófico 2001, p. 73).

A definição tradicional da noção (sublinhada) se assevera insuficiente, na medida em que os complementos da definição, apresentados de fato como essenciais, não são dedutíveis da formulação inicial. Daí a postura de superenunciação do autor, em relação a um princípio filosófico obscuro e incompleto que torna necessário o recurso ao especialista, que se apropria em seguida de uma fórmula aforística mais conforme a seu ponto de vista e à natureza das coisas. Tem-se a impressão, rapidamente desmentida por um exemplo mais atento, de que o conteúdo super-enunciado corresponde à definição dogmática, mas não é mais exatamente o caso, pois os desafios foram deslocados, da "verdade sobre si" para a "verdade tal como é"

(6) Apresenta um exemplo de reformulação irônica em super-enunciação:

Ricardo Alarcon, um dos "talibãs" (ler também p. 7), ex-representante de seu país na ONU, toma altamente as observações sobre a evanescência do presidente "provisório", Raul Castro, irmão mais novo de Fidel ("Libération, 7/8): "Por que ele tinha que se mostrar? Ele não é uma vedete"

Isso é verdade! Desde quando um dirigente de democracia popular tem que ser acessível e atento a sua população! (Le canard enchaîné, rubrica "notícias breves", n 4476, 9 de agosto de 2006)

Em (6), a aprovação marca um acordo fingido, tanto que a reformulação irônica que segue, parecendo dar quitação a Alarcon, expõe um ponto de vista em total contradição com os valores que se esperam de um dirigente "castrista". 
EID\&A - Revista Eletrônica de Estudos Integrados em Discurso e Argumentação, Ilhéus, n. 12, jul/dez.2016.

\section{Exemplos de subenunciação}

O locutor volta a uma definição ou a um raciocínio a partir de um ponto de vista que não é o seu, dando a entender sinais de distância a respeito do que ele traz:

(7) BELEZA: A qualidade do que é belo ou o fato de ser. É necessário distinguir as duas noções? É o que sugere Étienne Souriau, em seu Vocabulário de Estética: "Quando se fala do belo, é-se levado a buscar uma essência, uma definição, um critério. Enquanto que a beleza, sendo uma qualidade sensível, pode ser o objeto de uma experiência direta e mesmo unânime" Essa distinção, sem ser absolutamente imposta, corresponde mais ou menos ao uso. $O$ belo é um conceito; a beleza, uma sorte (COMPTE-SPONVILLE, 2001, p. 84).

À primeira vista, somos tentados a ver aqui uma pista de coenunciação, o autor que adota o PDV de Souriau para dar, em seu lugar, uma fórmula que exprime fortemente a antítese desenvolvida em Vocabulário de estética. Mas a acumulação das marcas lexicais de distanciamento, acentuadas pelos advérbios ("essa distinção, sem ser absolutamente imposta, corresponde mais ou menos ao uso") convida a interpretar o fragmento, e mais particularmente o aforismo final, como da sub-enunciação em relação a um ponto de vista certamente dominante, mas pouco esclarecedor, cujo locutor/enunciador primário não se satisfaz mais plenamente.

Em (8), o jornalista é certamente o autor da mensagem, mas sua voz não se refere a seu ponto de vista. E nesse contexto polêmico que sedia as mensagens editoriais, a discordância é lida fortemente atrás de uma concordância de fachada:

(8) NICOLAS SARKOZY tem razão: vale mais mostrar claramente seus objetivos. Assim, ele acaba de anunciar que, sob sua presidência da República Francesa, o ministério da imigração será também o da Identidade nacional. Está bem, mas conviria ir mais longe. Seria necessário criar o ministério da Cultura tricolor, o ministério do Interior do Hexágono, o ministério da Educação Nacional e patriótica, o ministério da Agricultura e do Galo gaulês, o ministério da Defesa do solo sagrado, o ministério da Economia azul-branco-vermelho, o ministério dos Negócios bárbaros (para a Europa e os países distantes)... É claro, isso surpreenderia um pouco no início. Mas vocês verão, isso será feito muito rápido (F. Brochet, Editorial / rubrica "Le mot”, intitulada aqui Identité, Le Progrès, 10 de março de 2007).

O jornalista, enquanto locutor, reporta o ponto de vista do enunciador que, concordando com Sarkozy, propõe generalizar seu ponto de vista. Salvo as duas últimas frases de distanciamento, todo o resto é um discurso irônico 
EID\&A - Revista Eletrônica de Estudos Integrados em Discurso e Argumentação, Ilhéus, n. 12, jul/dez.2016.

que, com certa má-fé, orienta e engrossa o ponto de vista adverso ao ponto de torná-lo contraprodutivo. A diferença em relação a (6) é sensível, na medida em que o PDV expresso pelo jornalista é imputado a Sarkozy.

Que primeiro balanço podemos fazer desses exemplos, sem nos apressarmos na diversidade das marcas?

Em primeiro lugar, nós dizemos muito co-, super- e sub-enunciação, e não co-, super- e sub-locução, porque as relações entre locutores não são diretamente proporcionais à quantidade de palavras pronunciadas: nesse plano, como veremos mais detalhadamente, a distinção locutor/enunciador faz particularmente sentido, na medida em que um locutor pode falar muito sem que seu PDV seja interacionalmente dominante. Ser super-locutor não implica ser super-enunciador: em (8), mesmo que o jornalista seja o autor da mensagem, ele não é o enunciador desta. Inversamente, ser um pequeno falante (algo como "sub-locutor") não implica ser um sub-enunciador. Não é necessário falar muito para que um PDV estruture as trocas: é o que se produz quando um chefe, de rara palavra, vê seus subordinados falar por ele, colocando-se enquanto sub-enunciadores frente ao discurso de autoridade, ou quando um mestre deixa que seu PDV seja expresso pelos bons alunos que superam as expectativas da instituição ${ }^{10}$.

Em segundo lugar, a diferença entre super-enunciação e sub-enunciação é às vezes complexa: poderíamos escolher exemplos claramente contrastados, como (6) e (7), mas preferimos não ocultar os problemas: de fato, não há grande diferença, aparentemente, entre (6) e (8), e podemos explicar isso pelo fato de que em uma interação dialogal não consensual e desigual, se um estiver em super-enunciação, o outro estará em subenunciação. É verdade, mas isso não basta. $O$ critério decisivo é aqui o de instância dominante: em (6), há a super-enunciação porque é o locutor/enunciador citante (o jornalista) que emite um PDV dominante em relação ao enunciador citado. É o inverso em (8): o PDV dominante é o do enunciador citado, anterior, o locutor/enunciador citante (o jornalista) faz apenas desenvolver esse PDV, certamente distanciando-se deste.

Em terceiro lugar, cada postura de sub-enunciação, de coenunciação e de super-enunciação é passível de graus na adesão (ou não) dos locutores para com os PDV assim coconstruídos: dessa forma, a coenunciação é mais

\footnotetext{
${ }^{10}$ É outra questão determinar se esses sub-enunciadores estão convictos do que eles dizem ou realizam na cena.
} 
EID\&A - Revista Eletrônica de Estudos Integrados em Discurso e Argumentação, Ilhéus, n. 12, jul/dez.2016.

forte em (4) que em (3), a super-enunciação é mais marcada em (6) que em (5), e a sub-enunciação é mais forte em (8) que em (7). Todavia, "mais forte" é uma formulação ambígua: em um plano descritivo, ela significa que há mais marcas ${ }^{11} ;$ em um plano teórico, ela pode indicar uma ligação de proporcionalidade entre essas marcas e o engajamento dos enunciadores. É muito difícil justificar o estabelecimento dessa relação ${ }^{12}$; mais difícil ainda é recusá-la. Por isso insistimos em sua ambiguidade, sem querer fazer o recorte precisamente, porque é o jogo das interações que precisa dessa ambiguidade: como dizem tão bem Bourdieu e Culioli, a compreensão é um caso particular do mal-entendido... ele decorre do precedente que suas as marcas, sua frequência, sua variedade, sua disseminação indicam o engajamento dos enunciadores em tal postura: é um fenômeno quantitativo e qualitativo, função da quantidade dos dados linguísticos retomados pelo interactantes, lugares linguísticos de manifestação do acordo (importa, por exemplo, verificar se o PDV é comum unicamente em premissas, no contexto de predicação, ou partilhado "parte a parte", desde a maneira de "ver" as coisas e denominá-las até a maneira de afirmar algo a seu respeito), da frequência e da força das modalizações etc. Mas a raridade dessas marcas não significa de modo algum que os enunciadores não estão de acordo, ela pode mais simplesmente significar que os enunciadores estão de acordo sobre um PDV sem sentir a necessidade de manifestar um engajamento pessoal, ou ainda que a situação não implica tais manifestações pessoais: assim em (3), o acordo se exprime na construção do conteúdo proposicional $(C P)^{13}$, sem passar pelas

\footnotetext{
${ }^{11}$ Sem entrar aqui em detalhes que nos afastariam de nosso propósito, pode haver mais marcas na construção do PDV e na expressão da reação do co-, super-, sub-enunciador a respeito desse PDV. Cf. infra, o fim do parágrafo, e 2.2.

${ }^{12}$ A apreensão enunciativa de um discurso (o que faz com o locutor assuma seu enunciado, enquanto enunciador, porque seu discurso é julgado verdadeiro, em adequação com o real) é indiferente na escolha de um plano de enunciação engrenado (enunciação pessoal) ou desengrenado (enunciação histórica ou teórica). Certamente, mais a força ilocucionária é marcada, mais o locutor se investe de seu dizer, mas uma força ilocucionária fraca não suscita a não apreensão da verdade do enunciado pelo locutor/enunciador. Desapegar-se de seu dizer não significa de nenhuma forma apreendê-lo, trata-se do contrário, de uma tática de legitimação apoiando-se em uma garantia externa. Escolher tratar um conteúdo proposicional em função de tal e tal modalidade intrapredicativa, alética (necessário versus contingente, possível versus impossível), epistêmica (certo versus contestável, provável versus excluído), deôntica (obrigatório versus facultativo, permitido versus proibido) afeta a observação da asserção, sem atenuar mesmo assim sua apreensão. Ver Rabatel (2008).

${ }^{13} \mathrm{O}$ conteúdo proposicional (CP) é a informação contida em uma oração: não apenas aquilo de que ela trata, mas o ponto de vista do enunciador sobre o que ele fala: assim, em "a neve é branca", o $\mathrm{CP}$ versa sobre o fato de que a neve é branca e sobre o fato de que, na assertiva dada ao enunciado, o enunciador enuncia uma verdade geral. Ducrot, 1984, p. 205 considera como equivalente a CP e PDV. Assim faremos, mesmo se a equivalência não for tomada literalmente, na medida em que PDVs podem aparecer sem formar um predicação completa: certas expressões
} 
EID\&A - Revista Eletrônica de Estudos Integrados em Discurso e Argumentação, Ilhéus, n. 12, jul/dez.2016.

modalizações que redobram o acordo no plano do dizer. Por isso, é perigoso passar, sem precauções, de variáveis linguísticas a dados psicológicos sumários do tipo: "eles não estão de acordo uma vez que eles não dizem explicitamente que estão de acordo", "ele é sub-enunciador porque ele não está de acordo/não está seguro de si", "ele é super-enunciador porque ele é um líder".

Tendo sido exemplificadas as noções, é hora de examiná-las sob o ângulo de sua emergência e de seu pano de fundo científico, porque isso pesa sobre os métodos e explica o interesse por problemas aos quais as posturas entendiam trazer elementos de solução. Em uma primeira parte será abordado o pano de fundo filosófico e linguageiro das posturas enunciativas. $\mathrm{Na}$ segunda parte, será mostrado em que ele influencia certa concepção da enunciação, antecipando a importância da disjunção locutor/enunciador, do fenômeno geral do ponto de vista, da articulação enunciação/referenciação, em um contexto interacional. Em uma terceira parte, será feito um histórico das questões que conduziram, nos primeiros artigos escritos sobre a problemática, à emergência das posturas. Enfim, uma quarta parte procederá a uma ilustração a partir de um estudo de caso inédito.

o pano de fundo filosófico e linguageiro das posturas enunciativas de coenunciação, sub-enunciação e super-enunciação

Porque avaliar a necessidade de redefinir a coenunciação e de the acrescentar duas posturas complementares? Fazemos isso por razões descritivas, mas também com um olhar crítico sobre o substrato teórico subjacente às representações dominantes no campo da linguística.

\section{Cooperação, consenso e dissenso}

De modo geral, as representações da linguagem oscilam entre concepções ecumênicas ou pessimistas: é assim quando se fala a respeito da argumentação, apresentada tanto como filha da má-fé e da sofística (segundo uma leitura à maneira redutora dos sofistas), como lembra Plantin (1996). Podem-se incluir dentro das concepções (aproximadamente) ecumênicas todas as teorias que insistem na necessidade de comportamentos

emblemáticas, em certas comunidades discursivas, em certas épocas, são emblemáticas de PDV: assim da expressão "método global”, por ocasião dos últimos debates sobre a aprendizagem da leitura. 
EID\&A - Revista Eletrônica de Estudos Integrados em Discurso e Argumentação, Ilhéus, n. 12, jul/dez.2016.

colaborativos para comunicar e se compreender. Assim, da etnometodologia: em reação a uma abordagem sociológica determinista e sob influência das teorias interacionistas simbólicas de G. H. Mead, Garfinkel e Sacks priorizam uma concepção dinâmica dos fatos e das relações sociais, resultantes de interações dinâmicas em que não é possível haver jogo, nas negociações feitas pelos próprios atores, rotinas e ajustes permanentes que decorrem de processos cooperativos, a exemplo dos ajustes da conversa. Além disso, máximas conversacionais de Grice, da abordagem dos atos de fala em Austin (1970), Searle (1972 e 1982), Vanderveken (1988), notadamente por meio da análise das condições de êxito dos atos de fala visando suas incidências frente aos locutores presentes, aos ritos de interações em Goffman, dinâmicas de coconstrução processuais e de caráter consensual das interações em Mondada etc. Da mesma forma, finalmente, concepções da argumentação baseadas na verdade: lógica não formal em Hamblin (1970), pragma-dialética de Van Eermeren e Grootendorst (1992) ${ }^{14}$. Todas essas pesquisas, que decorrem de paradigmas e de objetivos muito diferentes, consistem, todavia, em uma representação aberta das relações humanas, como um jogo de lugares e posições (sem negar a existência das relações verticais entre os indivíduos), privilegiando de uma maneira ou de outra, em um grau ou outro, interações que funcionam sob o princípio cooperativo generalizado que contesta representações, mas são determinantes nas relações sociais. Ora, se o princípio cooperativo não for em si unilateral - ele pode ser acompanhado de frases de dissenso, mesmo se ele privilegiar mais o consenso, na medida em que a generalização de comportamentos sufocantes coibiram as interações -, não se pode interrogar a respeito do deslizamento que vai da cooperação efetiva, notadamente na análise das interações didáticas em que é de bom tom (há um politicamente correto em didática também) priorizar as relações harmoniosas dos sujeitos reunidos por um furioso e comunicativo desejo de aprender - para além dos conflitos cognitivos.

\section{Limites do binarismo nos polos e continua}

Ora, a linguagem através de seus usos sociais, não ganha nada em ser restrita a uma visão unilateral das coisas, no plano teórico ou descritivo. Se,

\footnotetext{
${ }^{14}$ A que se opõem os que privilegiam todo conflito, os golpes de força e manipulações ou que, ao menos, pensam que argumentação endurece os conflitos aprofundando os dissensos, a exemplo de Willard (1989) (cf. Plantin, 1996, 2005, p. 60ss)
} 
EID\&A - Revista Eletrônica de Estudos Integrados em Discurso e Argumentação, Ilhéus, n. 12, jul/dez.2016.

nos trabalhos, insistirmos mais sobre as situações dissensuais que sobre as consensuais, por um lado, e se privilegiamos mais as posturas enunciativas de sub-enunciação e de super-enunciação, mais que de coenunciação, por outro, não é para substituir uma concepção pessimista da língua e das interações por uma visão otimista, é para dar conta do real na diversidade.

Tem mais. As interações são, por natureza, processuais e instáveis, e ao observá-las ao longo do discurso, vê-se que elas se deixam mal caracterizar como decorrente de uma maneira clara e bem identificada de uma forma prototípica de consenso ou de dissenso. Certamente, existem interações francamente consensuais ou dissensuais, mas na maioria dos casos, reina uma grande labilidade interacional em que consenso e dissenso tomam formas pouco animadoras.

Dito de outra forma, o binarismo herdado mais de uma leitura vulgar do estruturalismo que do estruturalismo próprio, merece ser considerado com distância, para a análise das interações. Nos discursos, nas interações orais em contexto didático, os fenômenos não são nítidos sempre que não são obscuros e as marcas, desde que não haja bi-univocidade, podem acumular valores diferentes. As relações decorrem mais de continua, gradientes ${ }^{15}$, indo do dissenso para o consenso ${ }^{16}$, distanciando-se do dissenso para se aproximar do consenso, e passando por etapas que nós limitaremos arbitrariamente a duas $^{17}$, as da discordância concordante e da concordância discordante, segundo uma analogia com o processo em execução na narrativa, segundo Ricoeur (1983). Este, em Tempo e narrativa, insiste no fato de que a narração permite fazer a síntese de elementos heterogêneos reunidos em uma intriga: a discordância na concordância, em torno da experiência temporal do vivido (cf. a experiência agostiniana do tempo, em torno da distenstio animi ${ }^{18}$ ),

\footnotetext{
${ }^{15}$ Certamente, os continua não são uma panaceia. Há sempre a necessidade de, nas ciências e no domínio da transposição didática ainda mais, traçar fronteiras, generalizar, dar regularidades. Precisamos delimitar e pensar o movimento.

16 "Ou inversamente": é o que significam as duplas flechas no quadro seguinte. Regressando à formulação que acabamos de utilizar ("do dissenso para o consenso"), nosso quadros (publicado assim em Rabatel e Lepoire (2005) e Rabatel (2007b, c)) começam pelo consenso: poderíamos, em conformidade com a formulação que acabamos de usar, inverter o lugar do dissenso (à esquerda) e do consenso (à direita). Mas repugnamos isso, pois queríamos deixar pensar, pela única orientação (do sentido da leitura) do quadro, da esquerda para a direita, que haveria uma evolução natural do dissenso para o consenso. Ainda uma vez, no plano descritivo, as interações vão em todos os sentidos. Mas a questão pode se colocar nos planos ontogenético, sociológico ou político.

${ }^{17}$ A fim de evitar a multiplicação de categorias calcadas no real, sem poder explicativo.

${ }^{18}$ Agostinho refuta a tese cética do não ser do tempo insistindo na tripla presença do tempo: o presente do passado, através da memória, o presente do presente através da intenção, o presente
} 
EID\&A - Revista Eletrônica de Estudos Integrados em Discurso e Argumentação, Ilhéus, n. 12, jul/dez.2016.

encontra-se invertida pela força da lógica narrativa com a intriga que põe a concordância na discordância finalizando o tempo (Bres, 1994, p. 54-58). Ora, se se desenrola a trama das relações entre consenso e dissenso - integrando o fato de que esses fenômenos jogam para um sujeito no estado de mónade, mas para um sujeito inserido na trama das relações com outrem -, diz-se que ao lado de uma representação prototípica do consenso como concordância concordante, e do dissenso, como discordância discordante, há lugar para os estados intermediários que são a concordância discordante e a discordância concordante:

\begin{tabular}{|llll|}
\hline $\begin{array}{l}\text { Concordância } \\
\text { concordante }\end{array}$ & $\begin{array}{l}\text { Concordância } \\
\text { discordante }\end{array}$ & $\begin{array}{l}\text { Discordância } \\
\text { concordante }\end{array}$ & $\begin{array}{l}\text { Discordância } \\
\text { discordante }\end{array}$ \\
Consenso & & Dissenso \\
$\begin{array}{l}\text { Coenunciação de } \\
\text { um PDV comum }\end{array}$ & $\begin{array}{l}\text { Superenunciação de } \\
\text { um PDV dominante }\end{array}$ & $\begin{array}{l}\text { Subenunciação de } \\
\text { um PDV dominado }\end{array}$ & $\begin{array}{l}\text { Enunciação dois PDV opostos } \\
\text { de de }\end{array}$ \\
\hline
\end{tabular}

Essa representação permite afinar a compreensão da coenunciação como concordância concordante, isto é, como coenunciação verdadeira, coconstrução pelos locutores de um PDV comum e partilhado, que os engaja enquanto enunciadores. A super-enunciação corresponde a uma concordância discordante, na medida em que a coconstrução desigual de um PDV dominante se inscreve em uma forma aparente de acordo, deportando a significação nova. Apresentando-se como a continuação do que precede, ela retira desafios novos que se impõem ao outro ${ }^{19}$. Quanto à sub-enunciação, ela decorre da discordância concordante, posto que a coconstrução desigual de um PDV dominado volta a dizer que o PDV efetivamente coconstruído não é partilhado pelos dois enunciadores, e que eles fazem entender essa discordância, à sua vontade ou sem seu conhecimento ${ }^{20}$. Essas duas últimas posturas indicam uma dissimetria na construção de um conteúdo proposicional mais ou menos assumido pelos dois locutores/enunciadores por

do futuro através da espera. Esse três tipos de tempo existem psicologicamente e, em razão de sua não coincidência, decorrem da distentio animi (distensão do espírito).

${ }^{19}$ Cf. (6): a aparente concordância entre o jornalista e Alarcon é de fato discordante: Há sim superenunciação no que o PDV do jornalista prevalece sobre o do dirigente castrista.

${ }^{20}$ Cf. (7): a sub-enunciação marca uma discordância concordante, que exprime, por falta de algo melhor, um PDV dóxico. 
EID\&A - Revista Eletrônica de Estudos Integrados em Discurso e Argumentação, Ilhéus, n. 12, jul/dez.2016.

meio de retomadas e reformulações, enquanto que a discordância discordante decorre da expressão manifesta e explícita de dois PDV antinômicos. Em resumo, só a coenunciação decorre de uma colocução que vai até a apreensão enunciativa de um PDV comum, ao passo que a subenunciação, como a super-enunciação consistem em uma co-construção de um só PDV, sem que os dois locutores/enunciadores se engajem tanto um quanto o outro, seja porque que o super-enunciador imponha seu PDV ao outro, fazendo como se seu PDV fosse só uma paráfrase do PDV do interlocutor, seja porque o sub-enunciador retoma o PDV do outro, distanciando-se, mas, sem substituí-lo por um PDV antagonista, ou, ao menos, sensivelmente diferente.

A análise desses fenômenos não repõe somente uma distância crítica a respeito de certas representações da linguagem, ela suscita também certo número de considerações metodológicas para dar conta de situações complexas, sem diluir por outro lado a análise propriamente linguística da linguagem. Daí a importância dos fenômenos de acumulação, no contexto de uma abordagem monista da língua, até mesmo para dar conta da dimensão reflexiva que é tão importante nos corpora didáticos.

\section{Acúmulo de pontos de vista}

Assim como lembra oportunamente Latour em um diálogo imaginário com um aprendiz de pesquisador, podemos ter diferentes pontos de vista sobre um objeto. Longe de conduzir ao relativismo, a articulação dos pontos de vista teóricos permite compreender melhor a complexidade objetiva dos objetos:

O que te faz pensar que "adotar um ponto de vista" significa "ser limitado"? ou ser especialmente "subjetivo"? [...] Se você pode ter diferentes pontos de vista sobre uma estátua, é porque a própria estátua tem três dimensões e te permite, sim, te permite olhar ao seu redor. Se uma coisa torna possível essa multiplicidade de pontos de vista, é que ela é muito complexa, intrincada, bem organizada e bela, sim, objetivamente bela.

[...] Não creia em todos esses absurdos sobre o fato de ser "limitado" em sua própria perspectiva. Todas as ciências inventaram meios para se deslocar de um ponto de vista a outro, de um quadro de referência a outro. [...] É o que chamamos de relatividade. [...] Se eu quiser ser um cientista e atingir a objetividade, eu devo ser capaz de navegar de um quadro de referência a outro, de um ponto de vista a outro. Sem tais deslocamentos, eu seria muito limitado em meu ponto de vista estreito (LATOUR, 2006, p. 210-213). 
EID\&A - Revista Eletrônica de Estudos Integrados em Discurso e Argumentação, Ilhéus, n. 12, jul/dez.2016.

Essa observação metodológica nos servirá de guia em nossa abordagem das interações em contexto didático; tanto é verdade que as relações entre interactantes obedecem a lógicas diversas, regulação das relações, gestão das faces e dos conflitos, divisão das tarefas, planificação e controle das atividades, verificações de atividades e de experiências, avaliações, balanços etc. As atividades de língua visam, logo, vários objetivos conjuntos, de socialização e de construção de si através da regulação pragmática das relações no grupo classe, de formação através da coconstrução dos saberes (linguísticos e não linguísticos) ${ }^{21}$. Desejamos poder dar conta desses objetivos no interior do paradigma enunciativo ${ }^{22}$, por meio de um estudo linguístico que integre enquanto necessidade os dados mímico-gestuais e proxêmicos, mas ainda a polissemioticidade das situações, notadamente em ligação com ações.

Mas, se considerarmos a linguagem na complexidade de seus contornos situacionais e acionais, é mais importante precisar sua concepção de linguagem. É no quadro do monismo que nós apreendemos os PDV, como fenômenos dialógicos de representação da subjetividade humana em seus esforços de conhecimento e de coconstrução de si, pela reflexão da práxis humana e através da mediação da linguagem. Tal concepção consiste na recusa de considerar o pensamento de um lado e a linguagem de outro.

\section{Monismo}

Advogamos, então, em favor de uma abordagem monista da língua e também, e mais a frente veremos suas interações, referindo-nos ao interacionismo social. Como escreve Merleau-Ponty:

[...] não há o pensamento e a linguagem, cada uma das duas ordens em exame se desdobra e envia um ramo à outra [...] As operações expressivas acontecem entre palavra e pensamento falante, e não, como se diz ligeiramente, entre pensamento e linguagem. Não porque elas são paralelas que nós falamos, é porque nós falamos que elas são paralelas (MERLEAU-PONTY, 1960, p. 26).

A unidade da percepção, do pensamento e da língua é própria de todo ser humano, ela é ativa e exemplar sempre que os meios de expressão ultrapassam a dimensão puramente denotativa/constatada do real, dando o

\footnotetext{
${ }^{21} \mathrm{Em}$ um plano linguístico, uma mesma marca pode acumular valores diferentes: assim para um conector, que exerce um papel seja de conexão lógica, seja de marcador de estruturação muito solta, como partícula do discurso; às vezes, o limite entre os dois não é fácil de estabelecer: ver Rabatel (2006).

${ }^{22}$ Outras palavras são possíveis e complementares, é claro.
} 
EID\&A - Revista Eletrônica de Estudos Integrados em Discurso e Argumentação, Ilhéus, n. 12, jul/dez.2016.

ponto de vista dos locutores, suas "perspectivas sobre as coisas", como escrevia Merleau-Ponty. Com efeito, é um dos ensinamentos mais estimulantes que se pode tirar dos trabalhos de Merleau-Ponty, no plano didático e pedagógico: sua concepção das relações palavra/pensamento não é somente válida para o "estilo" dos seres de exceção (escritores, por exemplo), mas ainda para indivíduos quaisquer, seres ordinários (alunos, professores, pesquisadores), que não são, no entanto, seres minúsculos.

Essa dialética entre palavra e pensamento vem no fundo de outras interações entre os outros e mim, que não seria possível considerar como entidades independentes, muito menos como pensamento e linguagem... Ela está no centro das atividades linguísticas nas quais os locutores refletem trocando e trocam refletindo.

\section{Reflexividade}

Existem diferentes significações da reflexividade enquanto distância da experiência, construção do espaço intersubjetivo, trabalho com/contra os discursos disponíveis, intensificação da dinâmica cognitiva nas interações, construção de identidade, construção do sentido da tarefa e da relação com a escola, sem esquecer a dimensão (meta)linguística (CHABANNE \& BUCHETON, 2002, p.3-13).

A reflexividade visa à análise dos processos linguístico-cognitivos e de coconstrução interacional dos saberes. Esses processos linguísticos não se limitam a atividades puramente metalinguísticas, uma vez que entram em jogo desde a construção dos conteúdos proposicionais (modo de apresentação dos referentes, escolhas enunciativas que presidem à atualização dos processos e à relação entre as noções), que inclui a problemática das modalidades e da modalização, até ao desenrolar das atividades metalinguísticas, em torno das glosas, paráfrases, reformulações ${ }^{23}$. Esses lugares linguísticos privilegiados em que se desenrola a reflexividade ativam as aprendizagens, segundo um círculo didático virtuoso que era resumido no subtítulo de nosso trabalho de 2004: Melhor (se) compreender para melhor (se) falar e melhor (se) aprender. Ele indicava que as trocas apreendidas em sua dimensão qualitativa (a triplicação dos melhores), reflexiva e interacional (os pronomes entre parênteses, que devem ser compreendidos como pronomes reflexivos, eu me falo, eu me

${ }^{23}$ Sobre essas questões, cf. Rabatel (2006 a, b, e 2007a, c). 
EID\&A - Revista Eletrônica de Estudos Integrados em Discurso e Argumentação, Ilhéus, n. 12, jul/dez.2016.

compreendo, eu me aprendo) e como pronomes recíprocos (eu te falo, eu te compreendo, eu te aprendo).

Em um quadro monista e interacionista, inspirando-se no interacionismo sociodiscursivo de Bronckart (1996, p. 22-43ss), a reflexividade cruza a problemática do dialogismo: primeiro do heterodialogismo, porque todo locutor é tomado na trama fechada dos discursos anteriores com os quais ele dialoga, aos quais ele concede, responde, objeta, adere, prolonga, etc. A abordagem monista da reflexividade cruza em seguida o autodialogismo, naquilo que o locutor, ao longo do processo de construção dos conhecimentos (que são também processos socializados de construção de si), dialoga consigo mesmo - raciocínio, pensamento interior, etc. - imaginandose em outros contextos (passados, futuros, hipotéticos), voltando às ilusões passadas e ultrapassadas, interrogando-se sobre tal crença, confirmando tal opinião, etc. (BRONCKART, 1996, p. 50-66) Nessa perspectiva, as ferramentas da enunciação asseveram-se preciosas, sobretudo se se referir, como é o nosso caso, a uma concepção larga da enunciação, que não privilegia a análise das marcas do aparelho formal da enunciação, mas os inscreve em uma abordagem larga da referenciação.

\section{A caixa de ferramentas enunciativa da análise das posturas}

\section{Locutor e enunciador}

Nosso trabalho versa sobre a disjunção locutor/enunciador de Ducrot (1984). Essa distinção, hoje mais e mais reconhecida, opõe-se aos trabalhos fundadores de Benveniste, que não distingue locutor e enunciador ${ }^{24}$, não mais, aliás, que os linguistas estrangeiros que utilizam indiferentemente locutor ou enunciador (speaker) - exceto se eles reivindicarem para si trabalhos de Culioli, Desclés ou Ducrot, que distinguem o produtor dos

\footnotetext{
${ }^{24}$ A fórmula de Benveniste que indica que "eu significa 'a pessoa que enuncia a presente instância de discurso contendo eu" (Benveniste, 1966, p. 252) criou duas leituras diferentes, uma considerando o enunciador de "maneira muito solta como um equivalente de locutor para designar o produtor do enunciado", o outro como "a instância cujo 'eu' é a pista, implicada pelo ato de enunciação em curso e que não tem existência independente desse ato" (Charaudeau e Maingueneau, 2002, p. 224). Assim, seja o enunciador a instância de produção do enunciado (e nesse caso não há enunciado sem enunciador), seja um efeito do enunciado, isso torna pensável a disjunção locutor/enunciador. Para uma apresentação mais aprofundada da questão, ver Rabatel (2004b), (2005a).
} 
EID\&A - Revista Eletrônica de Estudos Integrados em Discurso e Argumentação, Ilhéus, n. 12, jul/dez.2016.

enunciados das posições enunciativas que este último traz como contribuição na sua maneira de encarar as coisas ${ }^{25}$.

A separação locutor/enunciador permite dar conta do dialogismo interno à língua. Em Ducrot, a repartição dos papéis consiste em um locutor que apreende (ou não) certos conteúdos proposicionais, aprovando-os ou não. Quanto às fontes desses conteúdos proposicionais, são enunciadores. Assim, o locutor de um enunciado irônico põe em cena em seu discurso um PDV do qual se distancia: "Sim, é realmente genial mexer com seu colega!", diz o professor dirigindo-se a um aluno que acaba de mexer com um menor que ele: ele retoma um enunciador que, à maneira de um aluno, acha "legal" maltratar o mais frágil que ele, sem compartilhar de seu PDV. O exagero está em tal desacordo com a situação que as testemunhas devem compreender que o professor quer fazer compreender o contrário do que ele acaba de mencionar. Esse tipo de separação existe, seja nos contextos heterodialógicos (para evocar terceiros ou interlocutores, como no discurso indireto livre na terceira pessoa, nos fenômenos de ponto de vista, as negações, concessões, etc.), seja nos contextos autodialógicos, quando o locutor evoca seus PDV passados e futuros, faz hipóteses, ou modaliza um PDV: "Em outra situação, eu diria sim", "Eu não manterei mais a tese X tão abruptamente que outrora", etc.

\section{Enunciador, ponto de vista e conteúdo proposicional}

Ducrot define solidariamente o enunciador e o ponto de vista. Todavia, atrás da implicação recíproca dos termos (não ponto de vista sem enunciador, não enunciador sem ponto de vista), os dois conceitos não funcionam no mesmo nível, a noção de ponto de vista não sendo tão fundamental que o conceito de enunciador, mas exercendo um papel servil na definição do enunciador enquanto este último é doravante disjunto do locutor. Queremos como prova disso a ausência de critérios semânticos na definição do ponto de vista. Os parasinônimos "ponto de vista", "posição", "atitude" dizem eloquentemente que a expressão "ponto de vista" não tem mais importância que os dois outros e que o importante é que o ponto de vista não passe por "palavras" referidas a um locutor, autor de um discurso direto ou de um julgamento pessoal que implique a presença do eu.

${ }^{25}$ Mas o enunciador de Desclés corresponde ao locutor de Ducrot, e o locutor de Desclés corresponde ao enunciador de Ducrot. Essas diferenças de denominações são, todavia, secundárias em relação ao mecanismo de disjunção. 
EID\&A - Revista Eletrônica de Estudos Integrados em Discurso e Argumentação, Ilhéus, n. 12, jul/dez.2016.

Todo enunciado, enquanto combinação de um modus associado a um dictum, denota um PDV, mesmo na ausência do eu. Contudo, a estrutura modus dictum, herdada de Bally, não é sólida no plano linguístico: como observa Ducrot, a noção de modalidade "pressupõe que se possam separar, ao menos teoricamente, o objetivo e o subjetivo". Notadamente, ela exige que haja uma parte isolável da significação que seja pura descrição da realidade" (DUCROT, 1993, p.113). Ora, "o que se chama ideia, dictum, conteúdo proposicional não é constituído por nada mais [...] que por uma ou várias tomadas de posição" (Ducrot, 1993, p. 128) ${ }^{26}$. É necessário então buscar o ponto de vista não apenas no modus, mas também no dictum, posto que as escolhas que presidem ao modo de apresentação dos referentes são altamente reveladores do ponto de vista do enunciador, independentemente dos comentários do locutor que figuram no modus (cf. (3) e (4)).

O enunciador é notado, enquanto sujeito modal, não apenas por meio de seus comentários explícitos, ele se constrói através das indicações que afetam a construção dos objetos discursivos. Perceber um enunciador em um discurso implica buscar sua presença através da referenciação dos objetos do discurso (inclusive, até mesmo, na ausência das marcas do eu-aqui-agora), depois precisar se o enunciador é aquele que está em sincretismo com o locutor/enunciador primário ou precisar sua posição em relação a este último (acordo, desacordo, neutralidade). A referenciação não nunca é neutra, mesmo quando os enunciadores avaliam, modalizam ou comentam o menos possível. Essa abordagem dá conta de todos os tipos de PDV, inclusive PDVs implícitos, ou de PDVs naturalizados, tal como muitos deles existem no discurso didático ${ }^{27}$.

Interações do eu ao nós: o jogo das posturas na construção de um nós interativo e sua hierarquização

Essa divisão teórica locutor/enunciador, que faz deste último não um dublê do locutor, mas a fonte intradiscursiva de PDV que passa pela voz do locutor, é útil no plano linguístico e pragmático. Com efeito, a ruptura com o mito de unicidade do sujeito falante, tal como foi iniciada por Bakhtin, depois desenvolvida por todos os teóricos da enunciação e do interacionismo social,

${ }^{26}$ A definição de um PDV como combinação de um modus e de um dictum não é sólida no plano científico, pois não é possível distinguir do modus subjetivo um dictum que seria objetivo. Mas, em um plano prático, é útil considerar que o dictum se apresenta como objetivo.

${ }^{27}$ Ver Lidil 35, Rabatel e Grossmann (ed.) 
EID\&A - Revista Eletrônica de Estudos Integrados em Discurso e Argumentação, Ilhéus, n. 12, jul/dez.2016.

nos lembra que, nos nossos discursos e em outros, nós somos os outros, que os processos de construção de si - que passam pelo discurso - são em parte socializados, e que, nessa conjuntura, não somos os únicos enunciadores a entrar em jogo na construção dos PDVs que povoam nossos discursos. A crítica radical da unicidade do locutor, sob os avatares do diretor de filme, em Authier-Revuz (1995, 1998), está em forte congruência com as análises que priorizam os processos de coelaboração do sentido, haja vista a natureza profundamente interacional da comunicação, coelaboração que salta aos olhos na análise das interações orais, mas que não é menos presente também na escrita, sob formas diferentes e mediatizadas:

É necessário chegar a conceber o ouvinte como um verdadeiro colocutor, a interlocução como a raiz do sentido, responsável pelo dialogismo real do discurso. A interlocução se torna mais radical que a intersubjetividade. [...] Falamos com o outro e não apenas para o outro. Sou eu que falo, mas somos nós que dizemos (JACQUES, 1992, p. 192).

A coconstrução do sentido e da referência, fundamental nas interações face a face, participa também dos textos, em que a dinâmica do sentido passa pela confluência das enunciações reportadas ou a representação de pontos de vista que não são enunciações ${ }^{28}$; essa coconstrução atravessa de parte em parte o processo interpretativo ativado pelos destinatários, na escrita como na oralidade, sob formas variáveis segundo as situações e os gêneros do discurso.

Todavia, esse trabalho interpretativo só pode operar na base de uma reconstrução, de outra forma, do que foi desconstruído - este, a justo título, é o mito da unicidade do sujeito que fala: o que deveria ser reconstruído é o princípio de uma hierarquização das fontes, que se funda na lógica das trocas, e isso para além da mesma multiplicidade dos enunciadores que se fazem entender na cena enunciativa. Eis o que as diversas posturas enunciativas entendem como resposta. Mas tudo isso implica, do mesmo modo, uma

\footnotetext{
${ }^{28}$ Sob a condição de levar em conta a dimensão interacional que não existe em Ducrot e muito pouco em Culioli, segundo uma concepção da enunciação e da referência que não se limita a um querer dizer pré-estabelecido em cada um dos locutores. Em Culioli também, ainda que em um grau menor: assim a coenunciação corresponde a um cálculo do locutor/enunciador que integra antecipadamente em seu discurso das objeções do interlocutor, para melhor recolher seu acordo de seu interlocutor. Essa concepção do enunciador é dialógica, pois ela considera as reações potenciais do interlocutor, mas pouco dialogal e interacional, na medida em que ela não leva em conta a externalização dos enunciadores, em situações em que os locutores não são tão claramente mestres do dizer ou do querer dizer que o locutor/enunciador culioliano, dotado de um domínio discursivo, que não está nesse plano muito afastado da competência chomskiana! Ver (2005d).
} 
EID\&A - Revista Eletrônica de Estudos Integrados em Discurso e Argumentação, Ilhéus, n. 12, jul/dez.2016.

concepção da enunciação e da referenciação que não seja manchada pelo reducionismo - ver Rabatel (2005a).

Culioli, em seus encontros com Claudine Normand, fala tão significativamente do coenunciador "que é o espelho do enunciador (não do coenunciador exterior que é o interlocutor)" (Culioli e Normand, 2005, p. 155). Por outro lado, é esse enunciador exterior ${ }^{29}$, que não é o dublê do interlocutor, muito menos do locutor, que nós queremos seguir, a partir da coconstrução desigual e instável dos PDVs (ou conteúdos proposicionais), no quadro de uma concepção da referência que não corresponde a um querer dizer pré-estabelecido em cada um dos locutores. Com efeito, em situação ordinária, não se encontram sempre locutores mestres de seu querer dizer e que preveem da melhor forma possível, a partir de seus interesses, as reações de seus interlocutores. Nessas situações ordinárias, os pontos de vista se constroem tateando, nos planos linguístico e cognitivo, sem que seja sempre fácil saber se os PDVs coconstruídos pertencem plenamente a tal ou tal locutor ou são plenamente partilhados pelos interlocutores (coenunciação). As interações didáticas voltam muito particularmente a esse quadro, tanto as situações são desiguais e instáveis no plano interacional, tanto as coisas são complexas no plano cognitivo, e isso influi nas tomadas de palavra, no plano da elaboração dos conteúdos e/ou naquele do trabalho de formulação, a supor que os dois planos possam ser distintos. Dito isso, mesmo se Culioli não nos parece ir muito longe com a tomada da coconstrução interacional dos PDVs, resta, apesar disso, todo aquele que se antecipou mais nessa via, com relação a Desclés ou Ducrot.

\section{Gênese da problemática das posturas enunciativas, ao longo dos corpora}

$\mathrm{O}$ alargamento ${ }^{30}$ de nossos objetos de pesquisa, de análise linguística das interações orais ou a análise de discurso de textos não literários e o alargamento das teorias de referência que se seguiu a isso (didática, teorias das interações) favoreceram a emergência dos conceitos de super e subenunciação. Com feito, a coenunciação, sendo ela redefinida, permanecia imprópria para dar conta de situações interacionais e polissemióticas

\footnotetext{
29 De certa maneira, o "nós" de Francis Jacques, na citação supra, dá uma imagem de um enunciador exterior que transcende as posições dos enunciador-locutor e enunciador-interlocutor. Encontraremos uma ilustração disso em 3.2.

30 "Alargamento", com efeito, pois nós não abandonamos nossas primeiras problemáticas sobre PDV, mesmo quando elas foram seriamente desviadas.
} 
EID\&A - Revista Eletrônica de Estudos Integrados em Discurso e Argumentação, Ilhéus, n. 12, jul/dez.2016.

complexas. $\mathrm{O}$ acaso das publicações não devem delinear o fato de que nossas primeiras interrogações datam de 2000 (2204e) e de 2001 - Rabatel (2005C) -, e precederam então o artigo de Desafios 54, cuja publicação data do mesmo ano da redação do artigo, em 2002. Enfim, o artigo de Práticas publicado em 2003 é o último dessa fase de elaboração ${ }^{31}$.

Primeiro problema, primeiras investigações: análise das relações entre os enunciadores dos textos e das imagens de utopia

A primeira vez que nós propomos esse conceito de super-enunciação, tratava-se de analisar a relação entre um texto e imagens, a respeito de textos e de desenhos utópicos (a Utopia de More e A arquitetura considerada na relação da arte, dos costumes e da legislação de Ledoux), para determinar se as interações entre texto e desenho produziam uma super-signifcação que excede sua simples adição/confrontação.

Em Ledoux, as pranchas aparecem mais frequentemente depois do texto, que faz expressamente referência aos desenhos, ao ponto que não seria possível suprimir sem que toda a obra perca sentido. $O$ texto se apresenta como explicação progressiva de um pensamento condensado nos planos, tão forte que ela precisa ser desdobrada por seu criador/exegeta. Essa relação unidirecional do texto rumo ao desenho constrói a figura de um superenunciador (subsumindo os enunciadores do texto e do desenho) que manifesta uma preocupação constante de dominar a significação do desenho e as interpretações legítimas do texto.

Enquanto que o texto de Ledoux não deixa de remeter ao desenho, o texto de More fala de outra coisa além do desenho. Não estamos frente a um super-enunciador que controlaria a significação, mas frente a (ao menos) dois coenunciadores na origem de pontos de vista divergentes (texto sério versus especulação abstrata; sistema perfeito versus aperfeiçoável), sem hierarquização: aí onde Ledoux acredita tudo controlar e tudo explicar, More põe inicialmente indícios complexos, passíveis de interpretações contraditórias, sem escolher, a ambiguidade constitutiva sendo expressa desde o próprio título, uma vez que a palavra remete a dois étimos antônimos: "ou" + "topos"= não versus "eu"+ "topos" = lugar certo.

${ }^{31}$ Ver conclusão e bibliografia para uma lista completa de nossas publicações sobre as posturas. 
EID\&A - Revista Eletrônica de Estudos Integrados em Discurso e Argumentação, Ilhéus, n. 12, jul/dez.2016.

Segunda dificuldade: locutores e enunciadores em situação oral-gráfica e em interações dissensuais

A segunda situação que favoreceu a emergência da problemática das posturas consiste na intuição de que a noção de coenunciação parecia inadequada para dar conta de um processo dissensual - no entanto, colaborativo - de redação conversacional ${ }^{32}$ : Dois estudantes, um alemão, M., outro brasileiro, P. - ambos francófonos - deviam redigir um parágrafo argumentativo, depois de ter escolhido se eles eram a favor ou contra a existência de deveres para casa na escola primária. Os dois locutores tinham PDVs opostos ( $M$, contra os deveres, $P$, a favor), o que lhes fez infringir a consigna e adotar uma estrutura dissertativa com os dois PDVs, negociando de modo áspero uma conclusão abalada por contradições internas relevantes. Os desacordos bloqueiam a coconstrução de uma referência e de um coenunciador comuns. Daí haver incoerências na construção intersubjetiva, perpetuamente renegociada pelos interactantes, que se traduzem não apenas nas lutas de lugar entre interlocutores, mas afeta igualmente a construção da referência. Uma interação heteroglóssica tão dissensual não pode ser analisada com o conceito de coenunciador e requer o conceito de superenunciador, até mesmo para explicar as numerosas rupturas enunciativas e argumentativas (RABATEL, 2005C).

Com relação ao super-enunciador em Ledoux, ele é aqui mais marcado pela dinâmica interacional. Ele se manifesta nas sequências nas quais emerge um ponto de vista dominante. Haja vista o fato da existência de duas orientações argumentativas contrárias, tínhamos nomeado super-enunciador "P" e super-enunciador "M" 33 a instância fonte dos PDVs que exprimiam tanto o PDV de P (a favor dos deveres de casa) tanto o PDV de M (contra os deveres de casa), sendo entendido que os parênteses significavam que o PDV não se limitava à pessoa de $\mathrm{P}$ ou de $\mathrm{M}$, mas englobava os enunciados do interlocutor que apoiavam o PDV dominante. Por exemplo, nas sequências em que dominava o PDV de M, acontecia a P de formular (a título de hipótese, para clarificar o que ele queria dizer, ou par ironia) argumentos que iam ao sentido de $M$, argumentos que $P$ não utilizava, enquanto enunciador - mesmo se $M$

\footnotetext{
${ }^{32}$ Esse trabalho de negociação oral-gráfica entre dois estudantes foi objeto de duas publicações, $O$ processo redacional. Escrever com várias vozes, De Gaulmyn, Bouchard e Rabatel (2001) e Os processos da redação colaborativa, Bouchard et Mondada, (2005); a transcrição completa é publicada no segundo volume.

${ }^{33}$ Seria talvez mais justo fazer abstração do nome próprio dos enunciadores dominantes e falar de super-enunciador Pro e Contra ("A favor dos deveres de casa" e "Contra os deveres de casa")
} 
parecesse acreditar no contrário. Nesse momento, $\mathrm{P}$ se posicionava como subenunciador e participava da coconstrução de um PDV dominante no qual $M$ exercia o primeiro papel, e $\mathrm{P}$ um papel servil. $\mathrm{O}$ resultado dessa colaboração dos dois interlocutores (sem contar a contribuição de outros enunciadores intradiscursivos na origem de PDV indo ao sentido do PDV de $\mathrm{M}^{34}$ ), construía uma super-enunciação que correspondia a uma criação sincrética, no mesmo ponto em que o PDV super-enunciado co-formulado ia às vezes mais longe, por ironia, que o que pensava o locutor/enunciador dominante.

Terceira dificuldade: quando uma gestão atenta da poliofonia não acompanhaa hierarquização dos pontos de vista ou a sub-enunciação nas memórias profissionais

Com análise das memórias profissionais de professores estagiários de liceus e colégios - Rabatel (2002) -, a problemática da super/sub-enunciação se restringe a um domínio mais homogêneo, no plano linguístico. As relações que o discurso citante entretém com o discurso direto, no caso de acúmulo das fontes enunciativas, revelam a existência de textos coesivos e coerentes, mas opacos no plano da apreensão enunciativa, como no da orientação e da hierarquização de argumentos. Em princípio, o discurso direto tem por função fundamental ser um instrumento a serviço dos fins do locutor citante; todavia, esse valor pragmático do discurso direto se realiza sob forma paradoxal em professores estagiários do nosso corpus, através da emergência de um subenunciador, sempre que o locutor citante sofre para fazer entender seu ponto de vista diante daquele dos locutores citados, exceto para exprimir uma adesão aos textos oficiais e às autoridades intelectuais. Essas montagens de citação sem reformulação clara traduzem a dificuldade do escrevente em se posicionar em relação aos saberes constituídos - cf. igualmente Boch e Grossmann (2001) - dificuldade que, por cima, remete à maneira como esses saberes foram ensinados, de modo não historicizado, segundo um procedimento acumulativo que evacua os desafios dos saberes.

\footnotetext{
${ }^{34}$ A exemplo dos pais sobrecarregados de trabalho ou pouco formados, que não poderiam ajudar seus filhos a fazer seus deveres e aumentariam as desigualdades escolares.
} 
EID\&A - Revista Eletrônica de Estudos Integrados em Discurso e Argumentação, Ilhéus, n. 12, jul/dez.2016.

Quarta dificuldade: sobre a gestão das relações entre personagens, entre autor e personagens, entre autor/diretor, personagens e... leitores/público

As interações teatrais se definem constantemente pela dupla enunciação: por cima as trocas entre um personagem e outro, o autor (ou o diretor) se dirige a outro destinatário. Mas, além do fenômeno não ser próprio do teatro, convém interrogar-se sobre as instâncias na obra: a terminologia da dupla-enunciação remete ao uso de Benveniste que mascara as diferenças entre o locutor no início da mensagem e o enunciador que o assimila. Ora, considerada sob o ângulo da assimilação, a dupla enunciação pode ser analisada como coenunciação, mas também sub- ou super-enunciação.

Em primeira análise, o autor, no seu papel de criador, põe-se como superenunciador com relação a seus personagens e a seu público, em razão da dupla enunciação que o faz dirigir-se a seu público ou a seus pares acima de seus personagens. A postura de sub-enunciador é também observável, se ele escrever sob demanda econômica ou política, sem margem de manobra. As reações dos leitores, do público e da crítica podem influenciar na encenação, até mesmo, às vezes, na escrita conjunta de peri-textos (cartas, prefácio, entrevista) que atenuam ou endurecem os traços de tal personagem, o ambiente de tal cena, os argumentos de tal tese etc. Em resumo, as reações do público podem conduzir o autor - ou o diretor - a clarear seu discurso (coenunciação), a edulcorá-lo (subenunciação), a endireitá-lo (super-enunciação).

De modo geral, o próprio diretor pode conceber sua intervenção no texto como coenunciação, para buscar ao máximo transcrever o que o autor quis dizer, atualizando a mensagem deste. Ele pode agir em sub-enunciação produzindo uma encenação que respeita servilmente a Tradição ${ }^{35}$; ele pode, pelo contrário, afirmar-se como super-enunciador produzindo uma encenação radicalmente nova, que faz abstração do contexto de produção e do peritexto autoral, que produz uma "leitura" que contraria explicitamente certas análises do autor ou da tradição ${ }^{36}$.

A reflexão sobre as posturas enunciativas no teatro ${ }^{37}$ imbrica constantemente fenômenos linguísticos e escolhas interpretativas e lembra

${ }^{35}$ Cf. Barthes, 1955, 2002, p. 594.

${ }^{36}$ Cf. Barthes, 1954, 2002, p. 453, 461, 472.

${ }^{37} \mathrm{O}$ artigo Práticas $n^{\circ} 117-118$ - Rabatel (2003a) oferece um contraponto interessante na análise de interaçỗes orais ordinárias. Com efeito, se as interações nos textos são (re)criações artificiais, a massa do observável é frequentemente confiável, rica, mais condensada que as interações didáticas entre alunos jovens cujas competências linguísticas e/ou cognitivas são contraídas (idade, situação, posição do professor, aspectos temporais, programáticos etc). 
EID\&A - Revista Eletrônica de Estudos Integrados em Discurso e Argumentação, Ilhéus, n. 12, jul/dez.2016.

que as posturas de co-, super- e sub-enunciação entre personagens não devem ser coisificadas, ontologizadas. Nada seria mais falso do que assimilar uma postura enunciativa determinada por relações de força momentâneas entre locutores a traços psicológicos ou sociológicos permanentes. Assim, numerosas cenas que relacionam senhores e servos, com um servo muitas vezes dotado de enfermidades discursivas em situações de sub-enunciação com relação ao mestre, veem em certos momentos as relações se inverterem. Com efeito, de personagem em personagem (como na vida), as relações de co-, super- e sub-enunciação são sobredeterminadas pela dialogia interacional e pelo fato de que no próprio processo dialógico ressurgem ${ }^{38}$ problemas de lugar, papel, estratégia que são certamente determinadas pela situação objetiva anterior, mas que devem ser verificadas (ou contestadas) ao longo da interação: as relações vertical (status, lugar) e horizontal (familiaridade, distância) as relações afetiva (atração, repulsão) e ideológicas (consenso, dissenso) se unem e desunem sem cessar na interação, através de trocas simétricas e dissimétricas. Da mesma forma, nas interações didáticas, e não convém fechar os locutores em seus status (o professor, o aluno), nas atividades: se as posturas enunciativas apresentam um interesse didático, além de sua pertinência linguística, ele está aí.

\section{A variabilidade das posturas ao longo do discurso e da interação}

Mais do que retomar extratos de corpora analisados em outras publicações, preferimos prolongar o estudo de um corpus que já foi objeto de várias publicações anteriores - Griggs (2004), Rabatel (2004d e 2005b).

\section{Apresentação do corpus}

A aula de iniciação a uma língua estrangeira ${ }^{39}$, registrada em um $C E 2^{40}$ dos arredores de lioneses, em Caluire, apoia-se nos suportes de natureza

\footnotetext{
${ }^{38}$ Mantemos o prefixo re-, que certamente tem um valor intensivo, mas que indica, sobretudo, que as trocas são determinadas em princípio pela situação: esquecê-la seria cair no idealismo; mas, como acabamos de dizer, supervalorizar a situação voltaria a cair nos erros das teorias do reflexo, nos anos 1960 e 1970.

39 Corpus recolhido por A. Pastor, transcrição feita por S. Lepoire e A. Chalivet, por ocasião do seminário "ensinar a oralidade" (IUFM de Lyon e ICAR, Université Lyon 2). Convenções de transcrição: P: professor; A: aluno; =: elisão; -: palavra truncada; :: alongamento; _: insistência; o: pausa curta; oo: pausa média; 00o: pausa: 3 segundos (n) n segundos; //: sobreposição ; (x): inaudível; ': entonação ascendente; , : entonação descendente. (MAIÚSCULAS): indicações pontuais; MAIÚSCULAS+: indicações que se seguem até. A transcrição completa (28 páginas) é disponível sob demanda junto ao autor.
} 
EID\&A - Revista Eletrônica de Estudos Integrados em Discurso e Argumentação, Ilhéus, n. 12, jul/dez.2016.

audiovisual e escrita, com uma fita cassete que traz uma peça intitulada "Going for a walk" (GERNGROSS \& PUCHTA, 1996):

(9) The sun is shining. It is a beautiful day. Going for a walk. What's that ? You can hear a roll of thunder.

The big clouds in the sky. It starts pouring down. Run home!

Your hair gets wet.

Your face gets wet.

Your neck gets wet.

Your shirt gets wet.

Your jeans get wet.

Your shoes get wet.

Yuck!

O texto do áudio é acompanhado de sete imagens que ilustram a segunda parte do texto registrado, em negrito. O terceiro suporte, escrito, consiste em um conjunto de palavras-etiqueta depois de frases-etiqueta que transcrevem essa mesma parte da história. A primeira aula é consagrada à descoberta do cassete e à compreensão global da primeira parte da história, com a ordenação das imagens correspondentes ao texto do áudio, enfim, a um trabalho individual de colagem das imagens. A segunda aula é centrada na construção da morfologia do indicativo presente, a partir da observação dos cotextos com as realizações "get/gets", tomando como apoio primeiro o oral, depois as etiquetas, antes de uma fase de sistematização perturbada pelas diferenças linguísticas da representação da oposição não contável/contável, a respeito dos mesmos referentes, do francês para o inglês - "cheveux" versus “hair", "pantalon” versus “jeans”. O extrato (10), na segunda aula, remete ao momento em que a compreensão da natureza não contável de "hair" permite dar conta da construção "Your hair gets wet" sem invocar uma exceção à regra:

(10) $788 \mathrm{P}$ disse que: a terceira pessoa do singular seria com um s' o e a terceira pessoa do plural, não havia necessidade disso, oo mas é estranho' aí onde temos sempre problemas' com essa história de cabelos' hein'

$789 \mathrm{~A} \quad($ é l=) contrário, 00

$790 \mathrm{P} \quad$ Bem...sim' mas então: o é estranho / Ihe dão oo / damos uma 791 A25 /FORTE seria uma exceção' +/

$792 \mathrm{P}$ regra, /0o então seria uma exceção, o vamos - vamos escrever isso, já, hein' o your' o hairs:

793 A /masé (xxx)/

$794 \mathrm{P} \quad 000$ é isso o /hairs ( $x) /$ o your hair 000

$795 \mathrm{~A} \quad /(\mathrm{xx}) \mathrm{s} /$

$796 \mathrm{~A} \quad$ gets wet, oo gets

${ }^{40}$ NT.: Curso elementar 2, uma das séries da escolarização primária no sistema educacional francês. 
EID\&A - Revista Eletrônica de Estudos Integrados em Discurso e Argumentação, Ilhéus, n. 12, jul/dez.2016.

$797 \mathrm{P}$ gets' 000 your hair gets wet, oo como pode ser, como isso acontece' é estranho' ( $\mathrm{x}$ )

798 A26 pode ser que é porque o em francês dizemos cabelos' o e em inglês dizemos um cabelo, oo então, euh: o talvez que: 0

$799 \mathrm{P} \quad$ em inglês a gente escutaria' 0

$800 \mathrm{~A} \quad$ um ca/be/lo,/ um'

801 A26 leuh:/

$802 \mathrm{~A}$ cabelos

803 A26 um cabelo,

$804 \mathrm{P}$

805 A26

$806 \mathrm{~A}$

$807 \mathrm{~A}$

808 As

809 A25

810 As

os ingleses eles só teriam um cabelo na cabeça, os ingleses eles
não, mas /euh::/ como:
/não:/

$811 \mathrm{P}$ (x) barulho confuso $(\mathrm{x})$ professora $(\mathrm{xx})+$ entendê-lo, é bobagem' /bem eles falam de um cabelo particular/ / (BARULHOS CONFUSOS) /

812 A26 (x) explicar ( $x$ ) euh:: dois ( $x$ ) oo não me lembro mais, 813 As $\quad(x x)$

$814 \mathrm{P}$ /o que vou dizer sobre os ingleses, o (x)/ (x) algo que não

tem

$815 \mathrm{~A}$

$816 \mathrm{P}$ / $(\operatorname{xxxxx})$ /

$817 \mathrm{~A}$

$818 \mathrm{P}$

$819 \mathrm{~A}$

820 A25

$821 \mathrm{~A} 27$

$822 \mathrm{P}$

823 A27

$824 \mathrm{P}$

825 A25

$826 \mathrm{P}$ aprendido, o sim,

minha peruca'

$827 \mathrm{~A}$

$828 \mathrm{P}$

(x) de fato não podemos contar os cabelos, 0 logo se diria ' o tudo isso seria'

/GRITA cabeleira +/

GRITA minha peruca+/ /minha cabeleira,

minha peruca' c- é minha peruca, /sim, /

/SORRISOS/ minha peruca + e quando ela está bem implantada /oo / que ela é original'

$829 \mathrm{~A}$

830 P25 /cabeleira,

$831 \mathrm{P}$ cabeleira, o então de fato' os inglese' oo eles tendem a dizer' o minha' o cabeleira, oo e eles não dizem'oo porque o problema em inglês' é que é isso' oo é hair também, oo

832 As ah ah

833 A lah / são pelinhos,

834 A25 /(sim)/

835 A ah $/$ sim'l

$836 \mathrm{~A}$

837 A25 /SORRISOS pelinhos +/

$838 \mathrm{P} \quad /(\mathrm{xx}) /(\mathrm{x})$ não é, não é: muito besta aliás oo porque, realmente, é um pouco a mesma coisa' hein,

$839 \mathrm{~A} \quad /(\mathrm{xx}) /$ 
O professor, em 788, lembra as regularidades que permitem inferir a morfologia verbal do indicativo presente em inglês, não sem dar a crer que se trata de uma elaboração comum, enquanto que ele tomou uma parte determinante na extração da regra. Esta é contradita por "cabelo". A reflexão é complicada, primeiro pela diferença não contável/contável entre "hair" e "cabelos", em seguida porque o corpus oferece um número fraco de indícios para extrair regularidades estáveis. Os princípios da desinência de terceira pessoa do singular e do plural não se deixam extrair tão facilmente a partir do corpus. Com efeito, hair, o primeiro dos quatro enunciados no singular, é contável em L1, sob a tradução cheuveux, enquanto que é não contável em L2. Quanto a jeans, um dos enunciados no plural, ele oferece também problema, pois se trata de um plural interno, por divisão da unidade, e não de uma forma de plural externo, que se assevera menos complicada para a observação morfossintática. A esses problemas se acrescenta o fraco número de indícios complementares, em torno do sintagma nominal: your não marca o número diferentemente de votre/vos, tal como a variante her/his (his/her shirt, his/her shirts), propostos pelos alunos; enfim, o atributo não varia em inglês, ao passo que a variação em gênero, e, em uma medida menor, em número, é frequentemente sensível na oralidade, em francês. A respeito dessas dificuldades, a escolha de focalizar na exceção à regra, escrevendo no quadro, apenas, "Your hair gets wet", pode se discutir. Com efeito, é comparativamente aos outros enunciados que a observação e o raciocínio seriam pertinentes.

\section{Sub-enunciação do professor}

A sub-enunciação se explica pela vontade do professor de deixar falar os alunos, mais ainda porque ele mesmo flutua no domínio das noções e na sua exploração. De fato, o problema da morfologia da terceira pessoa do singular do indicativo presente em inglês é tratado aqui a partir da morfologia nominal de "cheveux", em francês... Ademais, não houve estabilização em torno da ideia que "gets" está no singular, o que convidaria a se interrogar sobre as especificidades sintático-semânticas de "hair" em inglês. A focalização sobre a estranheza de "cheveux" é a esse respeito muito surpreendente, porque ela mistura observações em inglês e em francês, sem nunca distinguir bem o plano das duas línguas... 
EID\&A - Revista Eletrônica de Estudos Integrados em Discurso e Argumentação, Ilhéus, n. 12, jul/dez.2016.

O que quer que seja, os alunos propõem explicações: depois de uma hesitação na pronúncia de "hair" zangadamente oralizada com o [s] do plural em 792 e 794, um aluno, em 798, formula logo a hipótese de que "pode ser porque em francês dizemos cabelos e em inglês dizemos um cabelo, logo, talvez que". O aluno é interrompido nas conclusões que ele busca tirar de sua hipótese. O professor a reformula em 799 de maneira ambígua: a formulação "ouviríamos em inglês" reconduz a hesitação entre inglês e francês. Ora, isso não tem muita pertinência ao dizer que se ouviria em inglês um cabelo: ouvese o que se diz, e a passagem do dizer, evocado pelo aluno, ao ouvir, é fonte de complicação. As respostas dos alunos, em 808, 803 ("um cabelo") ou em 802 ("cabelos") são confusas: fala-se do referente, do recorte do referente através do modo de apresentação do referente ${ }^{41}$ ? De toda sorte, as reformulações dos alunos e do professor, em 804, ("os ingleses, eles teriam apenas um cabelo sobre a cabeça") são, no plano da pertinência dos argumentos, muito aquém do que seria desejável ${ }^{42}$.

Sendo assim, que atitude o locutor adota, enquanto enunciador, reformulando 799 ("em inglês se ouviria"), com uma entonação interrogativa, e 804, dizendo que "Os ingleses, eles teriam apenas um cabelo na cabeça"? Em 804, o professor não ratifica uma formulação que versa sobre a descrição do referente. Esse distanciamento se refere ao ponto de vista expresso em 799, de maneira que se pode considerar que 804 marca uma sub-enunciação para com a dupla pergunta (799) e resposta $(799+800$ e 799+803). Em 804, o professor é sub-enunciador de um PDV que ele reporta, como um coenunciador. No plano linguístico, o conteúdo proposicional é realmente construído com referência ao PDV anterior. Se houver verdade, é naquela da

\footnotetext{
${ }^{41}$ Podemos evocar um mesmo referente (os cabelos) falando de um/dos cabelos, do cabelo, etc: Um cabelo é sólido: singular genérico inumerável, percepção densa, restituição massiva; Isso é cabelo!: singular genérico inumerável, percepção densa, restituição massiva; Isso são cabelos!: plural com valor qualitativo, percepção densa; A cabeleira é bela: singular genérico inumerável, percepção densa; Há aí uma/duas cabeleira(s) absolutamente magnífica(s): singular/plural numerável, percepção discreta. Ver Rabatel, 2004d, p. 147-149.

${ }^{42}$ Evidentemente, somos mais geniais depois do "ao vivo" na interação. A crítica não visa ao professor, não estamos certos que faríamos algo melhor. Mas isso não tira em nada a pertinência da crítica, enquanto momento de distanciamento e abstração feita pelas pessoas. A crítica, como a coruja de Minerva, só voa à noite. É sempre tarde, para o dia anterior..., mas, não desprovido de interesse para o dia seguinte... É toda a legitimidade da análise de corpus em formação inicial ou continuada. Abstraímos aqui a questão de saber se esse tipo de reflexão não é muito complicado nesse nível. Poderíamos pensar que sim. Se os alunos manifestam grandes atitudes no raciocínio, não é o caso de todos, e os esforços são talvez custosos, em relação ao que pode ser estabilizado. Mas sem separar do debate o que não temos muita competência, ao menos concordaremos com ideia de otimizar os esforços cognitivos.
} 
EID\&A - Revista Eletrônica de Estudos Integrados em Discurso e Argumentação, Ilhéus, n. 12, jul/dez.2016.

relação do PDV anterior: o professor retoma (modificando) sem querer atribuir a si a verdade do que é dito.

A partir de então, a sub-enunciação é ao mesmo tempo cognitiva e linguística: o professor parece reformular os dois PDV dos alunos (798, 800, 801, 802 ) escolhendo uma das hipóteses, ("um cabelo"), que não o satisfaz. Sua tática aqui é pregar o falso para atingir o verdadeiro, forçando uma resposta de maneira a fazer sair sua ausência de pertinência. Reconhece-se aí o que chamamos de a discordância concordante. No plano cognitivo, o professor retoma um PDV anterior, distanciando, mas não chega a substituir um novo PDV alternativo ao precedente. No plano interacional, a sub-enunciação passa por uma tática de deformação voluntária com fins didáticos: o PDV do professor modifica o do aluno (passagem de "dizer" a "entender"), mas essa modificação é apresentada como sendo de boa fé, ao menos por um bom motivo - o da emergência da verdade por um questionamento dos alunos que desvela as fraquezas de um raciocínio - sem querer responder em seu lugar. Como se o professor se fizesse mais bobo do que é para permitir aos alunos parecer que estão com vantagem. A técnica é aprovada, justificada, sendo que a intervenção do professor não infantiliza muito os alunos, ou não os perturba por movimentos centrífugos que afastam objetos didáticos.

\section{Super-enunciação do professor}

Se a sub-enunciação aparece em uma fase em que os alunos são convidados a refletir ativamente para encontrar uma solução, por outro lado, a super-enunciação parece, aqui, ligada a outra fase da atividade, a da institucionalização dos saberes. Nesse momento, o professor se posiciona como super-enunciador, no fim do extrato, quando ele faz o balanço do episódio, em 851, levantando o tom e começando seu turno de fala por um marcador iniciativo/conclusivo ("OK o FORTE então é por isso") que remete ao conjunto das discussões que precedem. Como em outras ocasiões, a formulação é ambígua (cf. "como é singular"): os pronomes "isso", "esse", visam ao verbo, ao nome, ao enunciado? Em contexto, consideremos que remetem a "hair", que é a palavra saliente, assim como o fazem os alunos que indicam várias vezes "cabeleira". O que quer que seja, a formulação é muito significativa: " então é por isso que de fato quando é singular" vale como um raciocínio que versa sobre o fato de que um nome no singular implica um verbo na terceira do singular, logo, "gets". O interessante é que a formulação 
EID\&A - Revista Eletrônica de Estudos Integrados em Discurso e Argumentação, Ilhéus, n. 12, jul/dez.2016.

é a do professor: ela não é muito explícita na relação entre o nome não contável singular "hair" e "gets", que consiste na conivência situacional e na ficção de uma formulação partilhada, comum aos alunos e aos professores. 0 raciocínio é de tal modo formulado que ele se impõe aos alunos, como decorrente da natureza das observações, como se essa ligação fosse suficientemente explícita para todos. Por outro lado, a reformulação é interrompida pela pergunta, "é o que como pessoa do singular, já": em resumo, essa questão incita os alunos a utilizar uma metalinguagem para ultrapassar a resposta factual e para dar uma resposta que se situe em um nível reflexivo mais geral, consistindo na utilização de certo vocabulário epilinguístico ("terceira pessoa do singular" ${ }^{43}$ ) que é ratificada em 855 depois repetida em 862 . A reflexividade se marca por meio da insistência com a qual o professor pronuncia as formas do singular para o substantivo, de um lado cometendo a similitude dos fenômenos em L1 e em L2, de outro, acentuando as formas pertinentes:

\footnotetext{
- em 855: "terceira pessoa do singular, e em francês também, minha cabeleira" - em 858: "é molhada"

- em 862: "é ela, é ela, sim, então é terceira pessoa do singular, gets o wet"
}

Os sublinhados indicam uma acentuação, os itálicos e negritos objetivam os laços fechados entre o substantivo e o verbo; a estrutura em quiasmo sublinha a semelhança da regra (tal substantivo, tal número implica tal pessoa verbal e tal desinência), do francês para o inglês, em que "hair" se reformula em seu equivalente gramaticalizado "ela" ("cabeleira" versus "cabelos") e onde "gets wet" não é mais uma exceção à regra. Em outros termos, o professor está em sub-enunciação em um plano triplo: no plano cognitivo, o professor retoma o PDV de alunos, PDV que, em ocorrência, são justos, reformulando-os de uma maneira mais abstrata, explicitando as etapas do raciocínio ${ }^{44}$. Esse PDV finge ser a reformulação pura e simples do precedente, mas, na realidade, ele vai mais longe que o PDV dos alunos, situando-se em um

\footnotetext{
43 Segundo Culioli, o epilinguístico corresponde à linguagem metalinguística de uso corrente utilizada pelos locutores não especialistas: verbo, substantivo etc. Não é certo que esses termos decorram todos do epilinguístico para todos os alunos...

${ }^{44} \mathrm{~A}$ explicação é real, mas ela é mais mostrada, entonativamente e gestualmente, que formulada com a ajuda de uma metalinguagem julgada aqui desapropriada. Estamos aqui diante de uma situação marcada por um duplo vínculo: explicitar mais com a ajuda de uma metalinguagem poderia ajudar a clarear as relações, mas por outro lado não é certo que o uso da metalinguagem traga alguma coisa para a compreensão do fenômeno. Para sua generalização, poderíamos discutir.
} 
EID\&A - Revista Eletrônica de Estudos Integrados em Discurso e Argumentação, Ilhéus, n. 12, jul/dez.2016.

nível mais englobante, como vimos em Rabatel (2006d ${ }^{45}$. No plano linguístico, a super-enunciação se marca através das redenominações aparentemente sinonímicas, com relação ao referente, mas não com relação ao universo de referência, que versa aqui sobre raciocínios gramaticais. Daí as insistências nas formas, para marcar a solidariedade entre formas, de um ponto de vista gramatical. No plano interacional, o professor está em superenunciação uma vez que seu PDV dominante faz o balanço do conjunto da transação extraindo a significação profunda dos procedimentos passados, ou orientando atividades futuras, sem deixar margem de manobra aos alunos: aqui, eles devem seguir o discurso da ciência, aplicar seus resultados. A postura não é certamente a mesma quando o professor adota uma postura de sub-enunciação para melhor deixar aos alunos a possibilidade de buscar ativamente a resposta.

\section{Coenunciações}

(10) mostra também, várias vezes, fases de coenunciação: acontece assim nos turnos $818+820 / 822$, nos quais os dois locutores, professor e aluno, coformulam um PDV comum. É igualmente o caso para $818+821 / 822$, com turnos superpostos que indicam que as duas respostas são confirmadas, de certo ponto de vista (substantivo coletivo referente a um conjunto não numerável), mesmo se um, que suscita um pequeno riso cúmplice, solicita ser modificado no contexto. O que quer que seja, apesar da ausência de explicação gramatical buscada, o PDV expresso pelo aluno no turno 817 ("de fato, podemos contar os cabelos") é confirmado como se fornecesse o quadro de predicação pertinente: "Logo diríamos, tudo isso seria minha": a exposição da cabeleira, a escolha do adjetivo possessivo no feminino singular orienta os alunos para a escolha de cabeleira. Na realidade, haja vista o caráter obrigatório/diretivo da seleção do determinante, a coenunciação, se não a limitarmos à produção de um PDV partilhado em uma só proposição, deve integrar também a observação do aluno no caráter não contável de "cabeleira" ou de "hair" em inglês, em 817. Constata-se assim que a coenunciação não tem exatamente a mesma medida conforme se privilegia o critério propriamente linguístico (coprodução pelos dois locutores/enunciadores de um PDV partilhado, em uma assertiva) ou se

45 Essa super-enunciação ganha em ser articulada com a dimensão cronogenética da construção/circulação dos pontos de vista, assim como observa a justo título Sensevy. 
EID\&A - Revista Eletrônica de Estudos Integrados em Discurso e Argumentação, Ilhéus, n. 12, jul/dez.2016.

antecipem preocupações cognitivas, mais flexíveis, que transbordem no quadro de uma assertiva, em conteúdos proposicionais distintos, mas que têm a mesma orientação argumentativa, como é o caso aqui.

Da mesma forma, em 845-849: nessa sequência lateral, o aluno A26, no prolongamento de suas tentativas anteriores (em 789, 805, 812) propõe um equivalente a "hair", a partir das diferenças entre calças/calça: a coisa permanece implícita e não é objeto de exploração desenvolvido para toda a turma, porque "calça" não se emprega tão bem quanto "hair" na demonstração ${ }^{46}$, na medida em que o plural inglês tem seu equivalente em francês e não perturba tanto quanto se fosse necessário passar do plural inglês para o singular francês. Dito isso, temos aí um belo exemplo de coenunciação.

É tentador fazer observar que as duas situações mostram uma real colaboração e igualdade entre alunos e professores, enquanto sujeitos que conhecem e refletem. É um fato, mas nós nos reservaremos de tirar dele conclusões normativas segundo as quais a coenunciação implica sujeitos que conhecem, ou inversamente, que a reflexão comum versa automaticamente sobre a coenunciação. De fato, esse gênero de raciocínios não se sustenta no plano científico: da mesma forma que podemos dizer besteiras ou pensamentos profundos em qualquer registro ou plano de enunciação, não há ligação entre tal postura e a verdade... Seria necessário dizer também que as fases de balanço implicam a super-enunciação ou as fases de atividade a subenunciação... Mas a ausência de laço automático não significa que não haja possíveis afinidades: se de um ponto de vista interacional ou cognitivo, podese esperar mais tal postura, ainda é necessário verificar isso no plano linguístico.

\section{Rápido balanço}

Com a observação precedente, abre-se o capítulo do balanço e das advertências. No plano dos lugares - não mais no das atividades -, não há correlação entre coenunciação e igualdade, super-enunciação e dominação (cognitiva, estatutária, sexual etc.), sub-enunciação e inferioridade. Assim, a coenunciação não implica que os locutores sejam pares, que partilhem as

${ }^{46}$ Cf. a existência de dois plurais distintos: plural por adição de unidades ou plural externo: cavalo/cavalos, mesa/mesas; plural por divisão da unidade ou plural interno: (par de) tesouras, óculos, lentes, calções, calças. (Wilmet, 1998, p. 59-60). 
EID\&A - Revista Eletrônica de Estudos Integrados em Discurso e Argumentação, Ilhéus, n. 12, jul/dez.2016.

mesmas opções intelectuais ou ideológicas. Da mesma forma, não é obrigatório que super-enunciador corresponda a um status sociológico ou político dominante, a uma dominação intelectual: tal como é possível proferir besteiras em uma enunciação teórica, pode ser que tal PDV dominante não se assevere o mais pertinente - Rabatel (2004a). Assim também para a subenunciação. É necessário distinguir o que decorre de uma postura obrigada de uma postura escolhida: assim, o subenunciador pode exprimir um PDV dominado em referência/reverência a uma autoridade por polidez, respeito, admiração, submissão, livre adesão, alienação ou fingimento, etc. Seria então redutor coisificar as posturas em função dos lugares ou estratégias até mesmo das situações ou intenções. Por outro lado, a contribuição das posturas na dinâmica dos lugares é preciosa: com efeito, as relações de co-, super- e subenunciação são sobredeterminadas pela dialogia interacional e pela situação objetiva anterior, mas elas devem ser verificadas (ou contestadas) ao longo da interação. Isso não significa que as posturas não dizem nada sobre a implicação dos locutores na construção dos lugares ou das atividades, mas que nada é predeterminado nem automático.

Quaisquer que sejam as dificuldades de marcação, nas quais não nos deteremos aquii $^{47}$, as posturas tornam serviços descritivos e interpretativos incontestáveis em análise de discurso, para os discursos científicos Grossmann e Rinck (2004) -, filosóficos ou religiosos - Rabatel (2004b, c, 2007b) -, literários - Rabatel (2003a), (2005e), (2006a, c), (2007a) -, mediáticos - Maingueneau (2004) e (2006), Marnette (2004), Laborde-Milaa e Temmar (2006), Lopez-Munoz (2006), Rabatel (2005a) -, assim como para as interações - Vion (2004), (2005) e, notadamente, para as interações em contexto didático - cf., além das referências citadas, Rabatel (2004a), (2005b, c, d), (2006d), (2007c), Rabatel e Lepoire (2005).

Haja vista a dimensão didática desse trabalho, queríamos, para concluir, insistir no interesse estratégico das posturas enunciativas: porque elas estão na intersecção dos dados linguísticos, cognitivos e interacionais, elas se asseveram ferramentas preciosas para as didáticas. Nós ilustraremos isso, para concluir, centrando-o na noção de contrato didático - crucial no exemplo (10) -, ligado às noções refinadas de devolução, de cronogênese e topogênese - ver Reuter et al. (2007). O contrato didático entre professores e alunos, na situação, não pode validamente abordar o estudo das interações, das

${ }^{47}$ Ver Rabatel, 2004a e 2004b, p. 12. Essa questão merece mais que uma nota... 
EID\&A - Revista Eletrônica de Estudos Integrados em Discurso e Argumentação, llhéus, n. 12, jul/dez.2016.

regulações que elas geram assim como determinações que as autorizam, sem cruzá-la com dados cognitivos e sem medir os investimentos dos enunciadores nesse trabalho, o que implica a compreensão dos cálculos interpretativos que se constroem nos interactantes, na base dos dados linguísticos e interacionais. A importância dada à construção dos pontos de vista, na coelaboração das posturas, fornece indícios para dar conta dos êxitos do contrato como de suas disfunções. De uma maneira geral, as posturas dão conta ao longo das interações do caráter movente de um contrato em constante coconstrução, com suas fases explícitas ou implícitas, como acabamos de ver em torno das discussões sobre "cabeleira", cuja finalidade última versa sobre a resolução do que apareceria como um desrespeito à regra de concordância da terceira pessoa do indicativo presente. As posturas esclarecem, primeiramente, a palavra e o papel do professor, a natureza de suas relações contratuais com os alunos, segundo seu comportamento frente às propostas dos alunos, segundo as atividades e os momentos ${ }^{48}$, mas elas são também preciosas para a análise das relações que se estabelecem entre alunos, como para aquelas que versam sobre as relações com as atividades, mostrando como os alunos podem se tornar atores e coconstrutores do saber ${ }^{49}$, tomando um parte ativa nos processos de devolução.

A análise detalhada das posturas enunciativas revela que os alunos não são os espectadores passivos de uma situação que se desenvolveria de pedaço em pedaço conforme o planejamento estabelecido previamente pelo professor. As posturas permitem assim seguir o percurso dos alunos nessa coconstrução, nos planos interacionais, linguísticos e cognitivos. A partir de então, as posturas são levadas a exercer um papel colaborador interessante para o estudo da cronogênes $\mathrm{e}^{50}$ e da topogênese, com o estudo dos diferentes lugares em que se constroem tarefas e atividades, em torno de certo número de objetos intermediários. Lembremos que Chevallard (1991) mostra notadamente que o lugar do aluno é determinado por tarefas de

\footnotetext{
${ }^{48} \mathrm{Cf}$. em (10), as mudanças de posturas adotadas pelo professor, que oscila entre sub-enunciação e super-enunciação, sem excluir fases de coenunciação.

${ }^{49}$ Segue-se que as posturas enunciativas podem aclarar a noção de transposição didática, na condição de considerá-la não sob forma de um processo de transformação de um saber constituído em um objeto de ensino externo em princípio pelo encontro efetivo dos alunos concretos, mas integrando no processo de transposição as interações entre alunos e professores (Cohen-Azria in Reuter et alii, 2007, p. 231).

${ }^{50}$ Assim, podemos ter a hipótese de que as posturas trazem indícios suplementares à segmentação das sequências (Lahanier-Reuter, in Reuter et alii, 2007, p. 225, Rabatel, 2006, p. 243-245), interessando-se pela parte da cronogênese relativa ao desenvolvimento on line da interação didática - Sensevy et al (2000).
} 
EID\&A - Revista Eletrônica de Estudos Integrados em Discurso e Argumentação, Ilhéus, n. 12, jul/dez.2016.

demonstração, o que constrói relações com os objetos de saber muito desiguais. As posturas confirmam esse tipo de análise (Rabatel, 2006, p. 230231, 239-241), mostrando que se um professor exercer um papel privilegiado no plano metalinguístico, no plano dos raciocínios (como no plano institucional), não é menos verdade que alunos podem também exercer esse papel, em tal ou tal momento (Rabatel, 2004, p. 49-55, e, no exemplo (10), os turnos $798,817,845)$ de maneira que mesmo se alguns lugares são mais reservados para o professor e outros para os alunos, não há nada de fatal nesse domínio, tanto os alunos, quanto as atividades ou o conteúdo de um saber podem perturbar os esquemas mais solidamente estabelecidos.

Definitivamente, as posturas esclarecem de acordo com uma dinâmica interna/externa o estudo do processo de devolução, pelos alunos - e de apoio, pelo professor - jogando com as ligações e separações que operam, nos planos cognitivo, interacional e linguístico. Não queremos dizer com isso que a coenunciação seria a postura privilegiada que daria conta do momento privilegiado em o aluno se apropria dos saberes e seus desafios, e faz seu "o dever de querer" aprender e fazer (Maulini, 2004, p. 8). Isso pode certamente passar pela coenunciação, mas também - e talvez mais frequentemente - por frases de super-enunciação ou sub-enunciação. Da mesma forma que o processo de devolução - ou as atividades de apoio - não corresponde a fases claramente timbradas, nem em um processo linear, ele não privilegia mais tal ou tal postura.

O interesse da noção de postura é então o de refutar toda abordagem de dissimetrias em termos de naturalização ou termos de reprodução determinista de desequilíbrios socioculturais ou institucionais que comandariam na relação pedagógica do exterior. Pelo contrário, as posturas alimentam a tese de uma margem de liberdade - e, portanto, de ação e inovação - nas interações das posturas, lugares, momentos e atividades em que se unem, desunem-se e se unem novamente as relações interpessoais com o saber, sem ignorar assim as determinações externas que os contraem. 
EID\&A - Revista Eletrônica de Estudos Integrados em Discurso e Argumentação, llhéus, n. 12, jul/dez.2016.

\section{Referências}

AMADE-ESCOT, Chantal. Milieu, dévolution, contrat. Regard de l'éducation physique. In: SALIN, Marie-Hélène; CLANCHE, Pierre; SARRAZY, Bernard (Dir.). Sur la théorie des situations didactiques. Grenoble: La pensée sauvage, 2005. p. 91-98.

AUTHIER-REVUZ, Jacqueline. Ces mots qui ne vont pas de soi. Paris: Larousse, 1995.

- Enonciation, méta-énonciation. Hétérogénéités énonciatives et problématiques du sujet. In: VION, Robert (Éd.). Les sujets et leur discours. Enonciation et interaction. Aix-en-Provence: Presses de l'Université de Provence, 1998. p. 63-79.

BARTHES, Roland. Le silence de Dom Juan; Dom Juan; Avignon, l'hiver. Guvres complètes. Tome 1. Paris: Seuil, 2002 [1954]. p. 453-455; p. 461-463; p. 472-475.

. CEdipe roi. CEuvres complètes. Tome 1. Paris: Seuil, 2002 [1955]. p. 594-595.

BOCH, Françoise; GROSSMANN, Francis. Se référer au discours d'autrui: comparaison entre experts et néophytes. Enjeux, n. 54, p. 41-51, 2002.

BRES, Jacques. La narrativité. Bruxelles: Duculot, 1994.

BRONCKART, Jean-Paul. Activité langagière, texte et discours. Pour un interactionnisme socio-discursif. Lausanne, Paris: Delachaux et Niestlé, 1996.

BROUSSEAU, Guy. Le contrat didactique: le milieu. Recherches en didactique des mathématiques. v. 9, n. 3, p. 309-336. Grenoble: La pensée sauvage, 1988.

. Glossaire de quelques concepts de la théorie des situations didactiques en mathématiques. Disponível em: http://perso.orange.fr/daest/guybrousseau/textes/glossaire_Brousseau.pdf.

CHABANNE, Jean-Charles; BUCHETON, Dominique. Parler et écrire pour penser, apprendre et se construire: l'écrit et l'oral réflexifs. Paris: PUF, 2002.

CHARAUDEAU, Patrick; Maingueneau, Dominique (Éds.). Dictionnaire d'analyse du discours. Paris: Seuil, 2002.

CHEVALLARD, Yves. La transposition didactique. Grenoble: La pensée sauvage, 1991 [1985].

CULIOLI, Antoine. Variations sur la linguistique. Entretiens avec Frédéric Fau. Préface de Michel Viel. Paris: Klincksieck, 2002.

; NORMAND, Claudine. Onze rencontres sur le langage et les langues. Paris: Ophrys, 2005. 
EID\&A - Revista Eletrônica de Estudos Integrados em Discurso e Argumentação, Ilhéus, n. 12, jul/dez.2016.

DANON-BOILEAU, Laurent; MOREL, Mary-Annick. Le locuteur vicariant. In: MERLE, Jean-Marie (Éd.). Le sujet. Paris: Ophrys, 2003. p. 235-246.

DUCROT, Oswald. Le dire et le dit. Paris: Minuit, 1984.

. A quoi sert le concept de modalité? In: DITTMAR, Norbert; REICH, Astrid (Éds.). Modalité et acquisition des langues. Berlin: Walter de Gruyter, 1993. p. 111-129.

FILLIETTAZ, Laurent (Éd.). Les modèles du discours face au concept d'action. Cahiers de linguistique française, n. 26, 2004.

GERNGROSS, Gunter; PUCHTA, Herbert. Do and understand. 50 action stories for young learners. Longman: Harlow; Essex, 1996.

GRIGGS, Peter. Articulation entre L1 et L2 dans la co-construction des savoirs langagiers en classe d'initiation à une langue étrangère. In: RABATEL, Alain (Éd.). Interactions orales en contexte didactique. Mieux (se) comprendre pour mieux (se) parler et pour mieux (s')apprendre. Lyon: Presses Universitaires de Lyon, 2004. p. 229-248.

GROSSMANN, Francis; Rinck, Fanny. La surénonciation comme norme du genre: l'exemple de l'article de recherche, et du dictionnaire en linguistique. Langages, n. 156, p. 34-50, 2004.

HAMBLIN, Charles L. Fallacies. London: Methuen, 1970.

JEANNERET, Thérèse. La coénonciation en français. Berne: Peter Lang, 1999.

KERBRAT-ORECCHIONI, Catherine. Les actes de langage dans le discours. Paris: Nathan, 2001.

LABORDE-MILAA, Isabelle; TEMMAR, Malika. Légitimités énonciatives dans le discours littéraire-médiatique: inscriptions subjectives et positions inégales. Semen, $\mathrm{n}$. 22, p. 145-159, 2006.

LEJEUNE, Pierre. Le brouillage énonciatif dans le compte rendu journalistique de documents techniques: le cas du Monde et des Notes de conjoncture de l'INSEE. In: LÓPEZ-MUÑOZ, Juan-Manuel; MARNETTE, Sophie; ROSIER, Laurence (Éds.). Dans la jungle des discours. Cadix: Publications de l'Université de Cadix, 2006. p. 237-247.

LÓPEZ-MUÑOZ, Juan-Manuel. L'auto-citation comme stratégie de persuasion à la limite de l'irresponsabilité. Étude de l'effet d'impartialité au moyen de l'effacement énonciatif dans les forums de presse. Semen, n. 22, p. 161-175, 2006.

MAINGUENEAU, Dominique. Hyperénonciateur et particitation. Langages, n. 156, p. 111-126, 2004. 
EID\&A - Revista Eletrônica de Estudos Integrados em Discurso e Argumentação, Ilhéus, n. 12, jul/dez.2016.

- De la surassertion à l'aphorisation. In: LÓPEZ-MUÑOZ, Juan-Manuel; MARNETTE, Sophie; ROSIER, Laurence (Éds.). Dans la jungle des discours. Cadix: Publications de l'Université de Cadix, 2006. p. 359-368.

MARNETTE, Sophie. L'effacement énonciatif dans la presse contemporaine. Langages, n. 156, p. 51-64, 2004.

MAULINI, Olivier. Mobilisation de ressources et conflits de savoirs: deux figures de l'articulation théoriepratique en formation des enseignants. Disponível em: http://www.unige.ch/fapse/SSE/teachers/maulini/deux-figures.htm. Texto de uma conferência proferida na Universidade de Genebra em 15 de junho de 2004.

MERLEAU-PONTY, Maurice. Signes. Paris: Gallimard, 1960.

MOREL, M.-A. Fusion/dissociation des points de vue dans le dialogue oral: intonation et syntaxe discursive. Cahiers de praxématique, n. 41, p. 157-189, 2003.

NONNON, E. L'enseignement de l'oral et les interactions verbales en classe: champs de référence et problématiques. Revue française de pédagogie, n. 129, p. 87-131, 1999.

PLANTIN, Christian. L’argumentation. Paris: Seuil, 1996.

. L’argumentation: Histoire, théories, perspectives. Paris: PUF, 2005.

RABATEL, Alain. La dynamique de la structuration du texte, entre oral et écrit. Enjeux énonciatifs des négociations autour du cadre de prédication, dans un énoncé bisegmental. In: DE GAULMYN, Marie-Madeleine; BOUCHARD, Robert; RABATEL, Alain (Éds.). Le processus rédactionnel. Ecrire à plusieurs voix. Paris: L'Harmattan, 2001. p. 67-88.

- Le sous-énonciateur dans les montages citationnels: hétérogénéités énonciatives et déficits épistémiques. Enjeux, n. 54, p. 52-66, 2002.

- L'effacement énonciatif et ses effets pragmatiques de sous- et de surénonciation. Estudios de Lengua y Literatura francesas, n. 14, p. 33-61, $2003 a$.

. Le problème du point de vue dans le texte de théâtre. Pratiques, n. 119-120, p. 7-33, 2003b.

- Déséquilibres interactionnels et cognitifs, postures énonciatives et coconstruction des savoirs: co-énonciateurs, sur-énonciateurs et archi-énonciateurs. In: (Éd.). Interactions orales en contexte didactique. Mieux (se) comprendre pour mieux (se) parler et pour mieux (s')apprendre. Lyon: Presses Universitaires de Lyon, 2004a. p. 29-66.

- L'effacement énonciatif dans les discours rapportés et ses effets pragmatiques. Langages, n. 156, p. 3-17, 2004b. 
EID\&A - Revista Eletrônica de Estudos Integrados em Discurso e Argumentação, Ilhéus, n. 12, jul/dez.2016.

- Stratégies d'effacement énonciatif et surénonciation dans Le dictionnaire philosophique de Comte-Sponville. Langages, n. 156, p. 18-33, $2004 \mathrm{C}$.

. Faciliter l'appropriation de la réflexion métalinguistique au cycle 3. Cahiers du Français contemporain, n. 9, p. 141-153, 2004d.

. Des images d'utopie(s) aux stylèmes de la pensée utopique. Pour une lecture non dogmatique des utopies. Protée, n. 32, v. 1, p. 68-79, 2004e.

. La part de l'énonciateur dans la construction interactionnelle des points de vue. Marges linguistiques, n. 9, p. 115-136, $2005 a$.

. Modalités, modalisations, apprentissage. Cahiers de l'institut de linguistique de Louvain, n. 31, v. 1, p. 47-74, 2005b.

- La narrativisation d'un texte argumentatif: résolution des conflits et argumentation propositive indirecte. In: BOUCHARD, Robert; MONDADA, Lorenza. (Éds.). La rédaction collaborative. Paris: L'Harmattan, 2005c. p. 227-256.

- Les postures énonciatives dans la co-construction dialogique des points de vue: coénonciation, surénonciation, sousénonciation. In: BRES, Jacques; HAILLET, Pierre Patrick; MELLET, Sylvie; NOLKE, Henning; ROSIER, Laurence (Éds). Dialogisme et Polyphonie. Approches linguistiques. Collection Champs linguistiques. Bruxelles: De Boeck Supérieur, 2005d. p. 95-110.

- Analyse énonciative et interactionnelle de la confidence. A partir de Maupassant. Poétique, n. 141, p. 93-113, 2005e.

. Les auto-citations et leurs reformulations: des surassertions surénoncées ou sousénoncées. Travaux de linguistique, n. 52, p. 71-84, 2006 a.

. Pour une analyse énonciative et discursive de la ponctuation du discours direct 'complet' en fin de phrase. Normes et usages, grammaire et linguistique. Neuphilologische Mitteilungen, n. 107, v. 2, p. 207-235, 2006b.

. Autocitations et autobiographie dans Du sens, de Renaud Camus. Texte, n. 39-40, p. 81-118, 2006c.

. Du rôle des postures énonciatives de surénonciation et de sousénonciation dans les analyses de corpus. L'exemple des reformulations, des connecteurs et particules discursives. In: GUERNIER, Marie-Cécile; DURAND-GUERRIER, Viviane; SAUTOT, Jean-Pierre (Éds.). Interactions verbales, didactiques et apprentissages. Recueil, traitement et interprétation didactiques des données langagières en contextes scolaires. Besançon: Presses Universitaires de Franche-Comté, 2006d. p. 221-248. 
EID\&A - Revista Eletrônica de Estudos Integrados em Discurso e Argumentação, Ilhéus, n. 12, jul/dez.2016.

. La re-présentation des voix populaires dans le discours auctorial chez A. Ernaux: surénonciation et antihumanisme théorique. Recherches textuelles, n. 7, $2007 a$.

. Répétitions et reformulations dans L'Exode: coénonciation entre dieu, ses représentants et le narrateur. Recherches linguistiques, n. 29, 2007b.

- Stratégie discursive de concordance discordante dans les ensembles reprises + reformulations (en contexte didactique). In: LE BOT, Marie-Claude; SCHUWER, Martine. (Éds.). Voies de la reformulation. Rennes: Presses Universitaires de Rennes, 2007c.

Prise en charge vs imputatibilité, ou la disjonction locuteur vs énonciateur revisitée à l'aune de la responsabilité. In: DE BRABANTER, Philippe; DENDALE, Patrick; COLTIER, Danielle. (Éds.). La notion de prise en charge en linguistique. Université d'Anvers, 2008.

; LEPOIRE, Solveig. La discordance concordante des discours représentés dans les séquences explicatives: hétérogénéité énonciatives et co-construction dialogique du sens. Cahiers de praxématique, n. 45, p. 51-75, 2005.

; CHAUVIN-VILENO, Andrée. La «question» de la responsabilité. Semen, n. 22, p. 5-24, 2006.

; GROSSMANN, Francis. Figure de l’auteur et hiérarchisation énonciative. Lidil, n. 35, 2007.

REUTER, Yves; COHEN-AZRIA, Cora; DAUNAY, Bertrand; DELCAMBRE, Isabelle; LAHANIER-REUTER, Dominique. Dictionnaire des concepts fondamentaux des didactiques. Bruxelles: DeBoeck, 2007.

SENSEVY, G., MERCIER, A; SCHUBAUER-LEONI, M.-L. Vers un modèle de l'action didactique du professeur. Recherches en didactique des mathématiques, v. 20, n. 3, p. 263-304. Grenoble: La pensée sauvage, 2000.

TRAVERSO, Véronique. La conversation familière. Lyon: Presses Universitaires de Lyon, 1996.

VAN EEMEREN, Frans H; GROOTENDORST, Rob. Handboock of Argumentation Theory. Foris, 1987.

VION, Robert. Modalités, modalisations et discours représentés. Langages, n. 156, p. 96-110, 2004.

- Séquentialité, interactivité et instabilité énonciative. Cahiers de praxématique, n. 45, p. 25-49, 2005. 
EID\&A - Revista Eletrônica de Estudos Integrados em Discurso e Argumentação, Ilhéus, n. 12, jul/dez.2016.

WILLARD, Charles Arthur. A Theory of Argumentation. The University of Alabama Press, 1989.

WILMET, Marc. Grammaire critique du français. $2^{\mathrm{e}}$ éd. Bruxelles: Duculot, 1998.

Forma de citação sugerida:

RABATEL, Alain. Os desafios das posturas enunciativas e de sua utilização em didática. Trad. Weslin de Jesus Santos Castro. EID\&A - Revista Eletrônica de Estudos Integrados em Discurso e Argumentação, Ilhéus, n. 12, p. 191-233, jul/dez.2016.

Recebido em: 16/11/2016

Aprovado em: 02/12/2016 